\title{
Drivers of fishing at the household scale in Fiji
}

\author{
$\underline{\text { Rachel Dacks }}^{1}$, Tamara Ticktin $^{2}, \underline{\text { Stacy D. Jupiter }}^{3}$ and Alan Friedlander $^{4,5}$
}

\begin{abstract}
Coral reefs sustain millions of people worldwide, yet in recent years, social, environmental, and climate change have caused major declines in coral reef fisheries. Small-scale coral reef fisheries research has largely focused on community-level drivers of fishing, ignoring the heterogeneities that exist within communities. We used social-ecological indicators from 20 coastal villages in Fiji to identify potential fine-scale, context-appropriate drivers of estimated household fish catch. Indicators were developed based on a review of the literature, discussions with local experts, and a pilot study. Using structural equation models, we found that importance of fishing to income, household fish consumption, livelihood diversity, travel time to market, and coral reef area all positively affect estimated household-level fish catch. Our results contrast with findings from other larger scale studies by identifying that households further from markets had higher fishing frequency. We highlight the role of middlemen in these small-scale fisheries, who have been largely overlooked as drivers of fisheries catch. Our findings emphasize the need for household-level analyses to better understand the complexities in coral reef social-ecological systems to more effectively manage small-scale fisheries in communities.
\end{abstract}

Key Words: coral reef fisheries; livelihoods; local ecological knowledge (LEK); market access; social-ecological systems; social network analysis; subsistence fisheries

\section{INTRODUCTION}

Fish play a significant role in the resilience of Pacific coral reef social-ecological systems. On the human side, fish provide a major source of protein (Bell et al. 2009, Teh et al. 2013, Charlton et al. 2016), are shared in complex social networks (Severance et al. 2013, Vaughan and Vitousek 2013, Kittinger et al. 2015), are central to cultural identity (D'Arcy 2006, Friedlander et al. 2013, Veitayaki et al. 2014), and provide an important source of income (Moberg and Folke 1999, Teh et al. 2009). On the ecological side, herbivorous fishes help keep algal levels in check (Hughes et al. 2007), maintaining open space for recruitment of reef-building taxa, which in turn enhances the resilience of coral reef ecosystems (Cheal et al. 2010). The preservation of higher trophic levels (e.g., sharks, groupers, jacks) helps maintain ecosystem balance (Heithaus et al. 2008). Coral reefs with lower densities of top predators have been found to have higher numbers of coraleating crown-of-thorns starfish (Acanthaster planci; Dulvy et al. 2004) and lower coral and coralline algae cover (Sandin et al. 2008).

Social, environmental, and climate change have caused worldwide declines in coral reef ecosystems (Gardner et al. 2003, Bruno and Selig 2007, Burke et al. 2011) and their associated fisheries (Newton et al. 2007, Mora et al. 2011). Recent studies have made important contributions to our understanding of human dimensions of coral reef social-ecological systems. Human population density has been documented as a positive driver of fishing pressure (Williams et al. 2008, Brewer et al. 2012) and negative driver of reef fish biomass (Mora 2008, Sandin et al. 2008, Cinner et al. 2009). Other social factors that affect fishing pressure and/or reef fish biomass include socioeconomic development, e.g., the presence of certain infrastructure and facilities (Cinner et al. 2009, Brewer et al. 2012) and fisheries management regime, i.e., traditional management, comanagement, national parks (McClanahan et al. 2006). Recent research has found an increase in fishing pressure (Brewer et al. 2012) and lower fish biomass (Cinner and McClanahan 2006, Cinner et al. 2013, Maire et al. 2016, McClanahan et al. 2016) closer to markets. Though our understanding of how social systems are linked to coral reef ecosystems has greatly improved, our understanding of what drives household-level fish catch is still lacking because the social measures that have been examined as drivers of fishing pressure are at the geographic community level or higher, e.g., human population density or presence of large-scale infrastructure such as schools and roads. Human communities, whether defined spatially or by social structure, are not homogeneous (Agrawal and Gibson 1999), and the variation of interests and behaviors of individuals or households within communities influence the state of resources (Kramer et al. 2009). Because behaviors can be managed, it is especially important to understand what influences individual and household-level fishing activities (Aswani et al. 2015).

In the Pacific, where human well-being is especially dependent on natural assets and kinship ties (Pascua et al. 2017, Sterling et al. 2017), factors that influence household fishing levels may include dependence on fish as a food source, importance of fishing to income, livelihood diversity, local ecological knowledge, and connectedness. Fish consumption in the region is high, though with recent urbanization, there has been a shift to an increasingly modern diet of imported goods and less local foods, including fresh fish (Charlton et al. 2016). One reason for this shift has been the increase in salaried incomes in urban areas, which is associated with a reduced dependence on fishing (Charlton et al. 2016). However, although there may be reduced dependence on fishing at the household level, other studies have found greater total fishing pressure closer to towns (Brewer et al. 2012). Proximity to markets or towns, commonly used as an indicator of market access (Brewer et al. 2012, Maire et al. 2016), has included measurements beyond simply distance, such as population size

\footnotetext{
${ }^{1}$ Department of Biology, University of Hawai i at Mānoa, Honolulu, Hawai'i, USA, ${ }^{2}$ Department of Botany, University of Hawai'i at Mānoa, Honolulu, Hawai'i, USA, ${ }^{3}$ Wildlife Conservation Society, Melanesia Program, Suva, Fiji, ${ }^{4}$ Pristine Seas, National Geographic Society, Washington, D.C., USA, ${ }^{5}$ Fisheries Ecology Research Lab, Department of Biology, University of Hawai'i at Mānoa, Honolulu, Hawai'i, USA
} 
(Brewer et al. 2009), but is not a complete measure of access to market because it has not taken into account transportation availability and does not consider all forms of monetary transactions. Middlemen, for example, are important intermediaries who provide links to markets, reducing the time and effort of fishers to market their catch. Although the role of middlemen has been documented in small-scale fisheries (Crona et al. 2010, Brewer 2011, Mangubhai et al. 2016), middlemen have been largely overlooked as drivers of fisheries catch. Because fish are not always sold in towns, a measurement of fishing income may be a better indicator of the influence of market integration on household fishing.

Artisanal fishers, like many rural residents in developing countries, have a high number of livelihood strategies (Allison and Ellis 2001, Cinner et al. 2010). The relationship between livelihood diversity and household-level catch is less certain. Although scenario-based studies show that increased livelihood diversity may increase a fisher's willingness to exit a fishery, there is a lack of evidence to show that fishers with more livelihoods have lower fishing effort (Brugère et al. 2008, Cinner 2014). In addition, in the Pacific, given the high levels of subsistence activities, it is important to consider all sources of livelihood rather than just those generating income (Campbell 2015). For example, households may partake in mat weaving not for selling, but for customary exchange or to contribute to cultural functions.

Local ecological knowledge (LEK) refers to knowledge systems encompassing world views, cultural practice, and beliefs that have developed over centuries and are constantly evolving (Berkes 1999). Examples from across the Pacific indicate that for centuries, LEK has influenced individual and community scale marine resource use (Johannes 1978, Veitayaki 2002). It is important to note that knowledge embedded within LEK systems has been used both to maximize efficiency of harvests (Foale 1998) and to restrict harvesting (Johannes 1978, Friedlander et al. 2013). Foale et al. (2011) highlight that applying knowledge for the purpose of conservation was never needed in places that were sparsely populated and did not experience resource depletions. Regardless of how LEK has been applied, there is increasing acknowledgement that LEK is invaluable for developing effective place-based natural resource management (Berkes et al. 2000, Poepoe et al. 2007, Thornton and Maciejewski Scheer 2012).

Resource sharing, including through reciprocal exchange, is one of the four important features of social capital identified by Pretty (2003). Resource sharing occupies a very important part of Pacific Island culture and facilitates maintenance of traditional linkages (Veitayaki 2002, Nabobo-Baba 2011, McMillen et al. 2014). In the context of these linkages, several studies have shown the extent and socio-cultural significance of fish sharing networks across the Pacific (Severance et al. 2013, Vaughan and Vitousek 2013, Kittinger et al. 2015). The spatial extent of exchange can be great and may stretch across island groups as in Micronesia, where coolers of reef fish are sent from outer islands to family members on the main islands (Oles 2007). In American Samoa and the Commonwealth of the Northern Marianas Islands, customary exchange was identified as a major driver of fishing effort (Severance et al. 2013).

We aim to better understand the drivers of household fish catch by asking (1) what direct and indirect social indicators drive household fish catch?; and (2) what is the role of proximity to town in influencing household fishing levels in areas in which middlemen are widespread? We address these questions using household-level, context specific, empirical data. We focus on Fiji where coastal communities are located in close proximity to reefs, communities have rights to manage these reefs (Matthews et al. 1998, Clarke and Jupiter 2010), and reef fisheries are highly important to local livelihoods (Teh et al. 2009). Despite their importance, many of Fiji's inshore reef fisheries are now threatened from overfishing, destructive and illegal fishing, and pollution, leading to socioeconomic hardship including loss of income and diet changes (Turner et al. 2007, Teh et al. 2009). In addition, road development, a government priority in the last decade, has greatly increased market access in many areas (Asian Development Bank 2015). As a result, stakeholders and managers are currently interested in better understanding drivers of fish catch in order to better manage marine resources throughout Fiji. We predicted that market access, LEK, livelihood diversity, seafood consumption, importance of fishing to income, reef area, and connectedness will be directly and indirectly correlated with estimated fish catch (Table 1, Fig. 1).

Fig. 1. Hypothesized structural equation model of socialecological drivers of household fishing catch. Black arrows are positive and grey arrows are negative effects. Hypothesized links are described in Table 1.

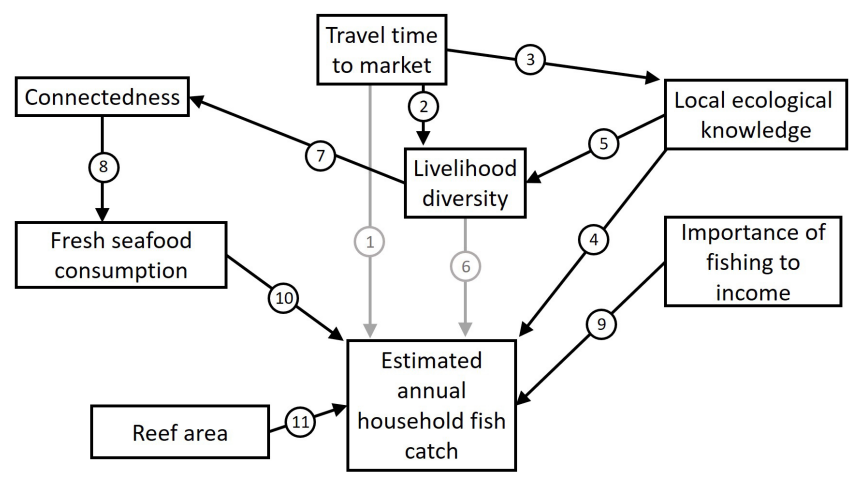

\section{METHODS}

\section{Study site}

Fiji is an archipelago consisting of over 300 islands, many of which are surrounded by fringing and barrier coral reefs. The population is just under 900,000 and about half of the country lives in rural areas (FBoS 2007). Most of the indigenous rural population lives in villages that comprise one or more tribes (yavusa; Ravuvu 1983). Rural villages rely heavily on their terrestrial and marine natural resources for subsistence and sale (Rawlinson et al. 1995, WCS 2012).

Although the national government recognizes the subsistence fishing rights, fishing grounds are legally owned by the national government with open access granted for subsistence with certain gear types, and fishing licenses are required for trade or sale (Matthews et al. 1998). However, customary fishing grounds (qoliqoli), extending to the outer reef, are informally divided into smaller units (kanakana) that are fished by single or multiple 
Table 1. Descriptions and justifications of links in hypothesized structural equation model (Fig. 1). The path number refers to the labeled model paths in Fig. 1.

\begin{tabular}{|c|c|c|}
\hline Path & Description of hypothesized links & Justification in the literature for hypothesized link \\
\hline 1 & $\begin{array}{l}\text { Households that have better access to markets may be more } \\
\text { inclined to sell a portion of their catch and thus fish at higher } \\
\text { levels. }\end{array}$ & $\begin{array}{l}\text { An increase in fishing pressure has been found closer to markets (Brewer et al. } \\
\text { 2012). }\end{array}$ \\
\hline 2 & $\begin{array}{l}\text { Households that have better access to markets may have a higher } \\
\text { chance of being formally employed in a full-time position and thus } \\
\text { not have the time or economic need to participate in additional } \\
\text { livelihoods. }\end{array}$ & $\begin{array}{l}\text { Households in more densely populated areas that were involved in formal } \\
\text { employment had fewer supplementary occupations (Cinner and Bodin 2010). }\end{array}$ \\
\hline 3 & $\begin{array}{l}\text { Households that have better access to markets may have lower } \\
\text { levels of local ecological knowledge (LEK). }\end{array}$ & $\begin{array}{l}\text { Increasing market integration has led to a loss of local knowledge (Cullen et } \\
\text { al. 2007) and breakdown in customary practices (Cinner and Aswani 2007). }\end{array}$ \\
\hline 4 & $\begin{array}{l}\text { Households with a greater knowledge of local fish may be using } \\
\text { this knowledge to fish at higher levels. }\end{array}$ & $\begin{array}{l}\text { LEK has been used to increase the efficiency of harvests (Johannes 1981) and } \\
\text { maximize catches (Foale 1998). In Fiji, master fishers of the gonedau clan have } \\
\text { been documented to have extensive knowledge of fish taxonomy (Thaman et } \\
\text { al. 2008). }\end{array}$ \\
\hline 5 & $\begin{array}{l}\text { Households with a greater knowledge of local fish may have higher } \\
\text { levels of LEK in other areas, which may enable them to have a } \\
\text { higher number of livelihoods. }\end{array}$ & $\begin{array}{l}\text { Fishers with increased knowledge of coastal resources have been found to have } \\
\text { higher occupational diversity (Cinner et al. 2010). }\end{array}$ \\
\hline 6 & $\begin{array}{l}\text { Households whose needs are met with a variety of sources may be } \\
\text { less reliant on any one source, such as fishing, and their household } \\
\text { catch will be lower than households with smaller livelihood } \\
\text { diversities. }\end{array}$ & $\begin{array}{l}\text { Households may spread their needs across a diversity of livelihood sources to } \\
\text { reduce risk (Allison and Ellis 2001). }\end{array}$ \\
\hline 7 & $\begin{array}{l}\text { Households with more livelihoods may have greater connectedness } \\
\text { if they have more skills and products to potentially share. }\end{array}$ & \\
\hline 8 & $\begin{array}{l}\text { Households that are more connected within their networks may } \\
\text { have higher fishing levels because they may be catching a surplus of } \\
\text { fish that is shared with other households. }\end{array}$ & $\begin{array}{l}\text { Customary exchange has been identified as a major driver of fishing effort } \\
\text { (Severance et al. 2013). }\end{array}$ \\
\hline 9 & $\begin{array}{l}\text { Households that depend more on fishing for an income source may } \\
\text { have higher fishing levels. }\end{array}$ & \\
\hline 10 & $\begin{array}{l}\text { Households who depend more on fish as a food source will have } \\
\text { higher fishing levels. }\end{array}$ & $\begin{array}{l}\text { Bell et al. (2009) document the strong reliance on fish for protein in the } \\
\text { Pacific. However, fishing pressure has been shown to decrease as dietary } \\
\text { dependency lessens (Turner et al. 2007). }\end{array}$ \\
\hline 11 & $\begin{array}{l}\text { Households with more accessible reef area to fish may have higher } \\
\text { fishing levels because there is a greater amount of habitat to } \\
\text { support the resource base. }\end{array}$ & \\
\hline
\end{tabular}

villages, with access granted by the chief of that village. Though not legally recognized, customary management over the qoliqoli and kanakana is still practiced in most rural areas in Fiji (Clarke and Jupiter 2010, Sloan and Chand 2016).

Urbanization, globalization, and integration into cash economies have all impacted traditional social structures and customary resource use. Access to markets has increased purchasing power, changing reliance on natural resources for food and income (Ravuvu 1988, Turner et al. 2007). School and church fees, medical and transportation costs, and purchase of imported goods has increased the need for income generating activities (Matthews et al. 1998). There is now less respect for the traditional roles of hereditary chiefs in mandating and enforcing natural resource management with recent national legislation and access to markets (Minter 2008, Jupiter et al. 2010, Sloan and Chand 2015).

\section{Household surveys}

To identify potential social drivers of fisheries catch, we conducted research in 20 indigenous Fijian coastal villages across five districts in Fiji from August to November 2014 (Fig. 2, Appendix 1). Districts were selected to represent a range of sociocultural, economic, and ecological conditions.
Fig. 2. Map of the Fiji Islands. Italicized names mark the three largest islands in the archipelago. Areas shaded in black are the five study districts. Markets where villagers from the study sites visit to sell and buy goods are marked with circles (towns) and star (capital city, Suva). Numbers in parenthesis denote the number of villages surveyed followed by the number of households surveyed.

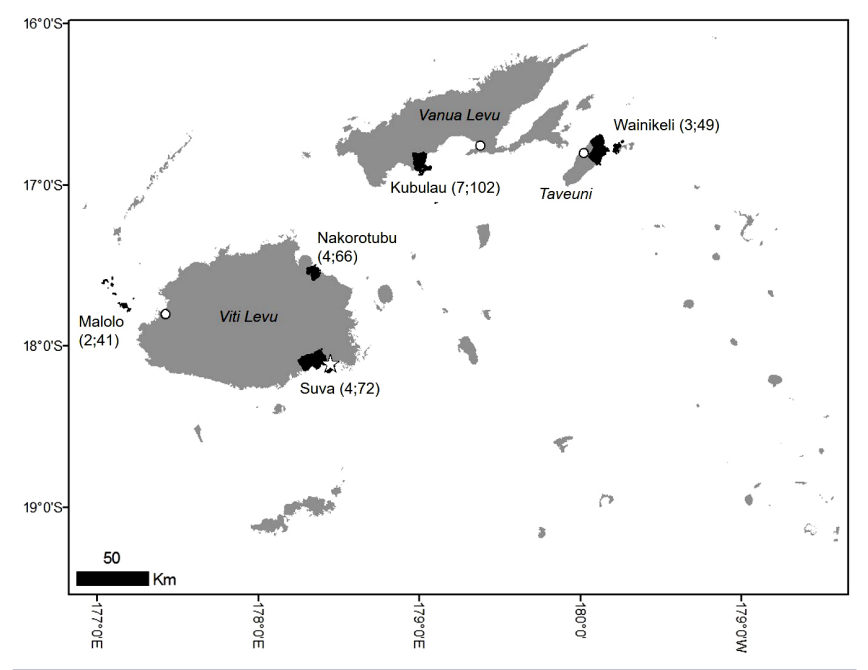


Table 2. Descriptions of potential social-ecological indicators of household fishing catch. 'Dependent variable

\begin{tabular}{|c|c|c|}
\hline Indicator & Description & Survey method \\
\hline Travel time to town & $\begin{array}{l}\text { Travel time (minutes) to reach the town in which most villagers travel to for buying and } \\
\text { selling goods, using the most commonly utilized mode of transportation }\end{array}$ & Key informant interview \\
\hline Distance to town & $\begin{array}{l}\text { The distance }(\mathrm{km}) \text { traveled by the most commonly utilized mode of transportation to the } \\
\text { town in which most villagers travel to for buying and selling goods. }\end{array}$ & Measured from Google Maps \\
\hline Market frequency & The number of times in a year that a member of the household visits town. & Household survey \\
\hline Income diversity & The number of income sources employed by the household & Household survey \\
\hline Livelihood diversity & $\begin{array}{l}\text { The number of livelihood sources employed by the household, which includes sources of } \\
\text { income and livelihoods that procure food and/or handicrafts for cultural offerings. }\end{array}$ & Household survey \\
\hline Local ecological & Index made up of standardized scores based on responses to questions about fish & Household survey \\
\hline knowledge & $\begin{array}{l}\text { identification, fish diets, timing of fish reproduction, and transmission of this knowledge } \\
\text { (Appendix 2). }\end{array}$ & \\
\hline Formal education & Highest level of formal education attained by adults in household & \\
\hline Connectedness & $\begin{array}{l}\text { The sum of the number of households the respondent's household shares with or receives } \\
\text { shared resources from. }\end{array}$ & Household survey \\
\hline Material wealth & $\begin{array}{l}\text { Sum of the number of appliances owned by the household from the following list: radio, } \\
\text { television, DVD player, mobile phone, generator, refrigerator/freezer, washing machine, } \\
\text { laptop/tablet }\end{array}$ & Household survey \\
\hline $\begin{array}{l}\text { Annual household } \\
\text { catch }^{\dagger}\end{array}$ & $\begin{array}{l}\text { Product of the annual number of household fishing days (summed across all gear types) and } \\
\text { the catch per unit effort for the different gear types (calculated using community catch logs). }\end{array}$ & Household survey; Catch logs \\
\hline $\begin{array}{l}\text { Fresh seafood } \\
\text { consumption }\end{array}$ & Average number of days per week the household consumes fresh seafood. & Household survey \\
\hline Reef area & Total area of accessible reef in district fishing grounds. & $\begin{array}{l}\text { Household surveys; Focus } \\
\text { groups; Millennium Coral } \\
\text { Reef Mapping Data } \\
\text { (Andréfouët et al. 2006) }\end{array}$ \\
\hline
\end{tabular}

In villages with fewer than 20 households, we invited all households to be surveyed. In larger villages, we surveyed a random sample of 20 households (Appendix 1 contains a list of villages with number of households and percentage surveyed). We conducted a total of 330 household surveys (Fig. 2). All survey activities were approved by the University of Hawai $i$ Institutional Review Board, Fiji Ministry of Education, local Provincial Offices, and highest ranking village elders within each community. Surveys were conducted with heads of households, which were defined as those who made household decisions. A household was defined as a group of people who regularly shared meals. Household interviews were structured surveys lasting approximately 45 minutes. Questions covered topics including socioeconomics, fishing and farming activities, ecological knowledge, resource sharing, and material assets (Table 2). Focus group discussions, participatory mapping exercises, and interviews with the village headmen were also conducted to better understand and triangulate village-level characteristics of resource management and market connections. All interviews were conducted in the Fijian language.

\section{Social network surveys}

A social network analysis of resource sharing between households in each village was conducted to measure connectedness, an important component of social capital. To conduct the social network analysis, households in each village were asked to provide the names of the other households in which they received or gave resources (e.g., fish, crops, prepared food) within the previous two weeks (Appendix 2). In order to assess the whole network, we sampled $\geq 80 \%$ of households. In villages where we surveyed $\geq$ $80 \%$ of households with household surveys, these questions were simply incorporated into the household survey. In villages where we conducted household surveys with $\leq 80 \%$ of households, additional households were given only the social network survey, so that the total number of households that were given the social network questions was $\geq 80 \%$.

Social network calculations were done using Visone software (Brandes and Wagner 2004). Degree centrality (the sum of the number of households the respondent's household shared with or received resources from) was used to indicate the household's connectedness. For the purposes of this analysis, we calculated degree from an undirected graph because we did not need to distinguish between giving and receiving of resources.

\section{Social indicators}

We measured a suite of social indicators in our household surveys based on a review of the literature and discussions with local experts from universities and nongovernmental organizations (Table 2). Survey questions that measured indicators of LEK were developed from a pilot study that was conducted in 2013 (Appendix 2). We calculated proximity to market as the distance along a road and/or boat path to town, as well as travel time to town and market trip frequency to take into account factors that are not represented in a simple distance measure, such as speed, frequency, and price of travel mode. Livelihood diversity was measured by the number of income sources the households had, as well as by the total number of livelihoods, which included nonmonetary sources used for food and cultural offerings. Importance of fishing to income was based on the respondent's ranking of their income sources.

To measure local ecological knowledge (LEK), we developed an LEK index that included standardized metrics of knowledge transmission $(20 \%)$, knowledge of fish identification $(40 \%)$, and 
knowledge of fish ecology (40\%; Appendix 2). We measured knowledge transmission by asking whether or not the respondent formally or informally teaches fish names to the younger generation(s). We measured knowledge of fish identification by asking for 20 local fish names (fishes were a combination of common and rare species; higher scores were given to specific names, lower scores were given to general or family names). We measured knowledge of fish ecology by asking about fish diets and the timing of spawning for groupers (family Epinephelidae), emperors (family Lethrinidae), and parrotfishes (family Labridae). Together these fish families were chosen based on their diverse functions, but also because they are important for subsistence, sale, and cultural events. Because there is documented information of some fish diets (http://www.fishbase.org), points were given to responses that match existing data for fish families. Because timing of spawning may vary spatially and temporally (Schemmel and Friedlander 2017), points were given to any response and no points were given to those who responded that they did not know. These scores provide an index of LEK but not a comprehensive measure (Zent and Maffi 2009). Because small differences in the index are not meaningful, we then ranked the scores from low to high based on three broader groupings.

To assess material wealth, the number of assets from a list of appliances were tallied using methods modified from McClanahan et al. (2008). Total reef area was calculated by overlaying the GIS layers of coral reef locations made available by the Millennium Coral Reef Mapping Project (Andréfouët et al. 2006) in ArcMap 10.4.1 (Esri 2016) onto a layer identifying reefs that are commonly fished. The second layer was created by asking respondents (in household interviews and focus groups) to identify on a map the reefs that they frequently access to harvest fish. We did not include all reefs within fishing grounds in the calculation of reef area because in some districts, distant reefs are not accessed. Though we intended to calculate the reef area from the kanakana, we calculated reef area at the district level because there was significant overlap in the use of fishing grounds between villages in the same district; households fished in areas outside of their kanakana, so kanakana area does not accurately reflect the size of the reefs being accessed.

\section{Estimated annual household catch}

We estimated total annual household catch from trip frequency estimates and catch per unit effort (CPUE) for each gear type. Two fishers each from 13 villages across Fiji completed training on recording catches in logbooks. Of these 13 villages, eight are located in four of the five districts in which household surveys took place. Fishers recorded all fishing landings in their village, in a haphazardly chosen 24-hour period once to twice a month over a six-month period and recorded information for each fishing trip, including gear type used. The biomass of individual fishes was estimated using the allometric length-weight conversion:

$$
W=a F L^{b}
$$

where parameters $a$ and $b$ are species-specific constants, FL is fork length in $\mathrm{cm}$, and $\mathrm{W}$ is weight in grams. Length-weight fitting parameters were obtained from Kulbicki et al. (2005). Total biomass was calculated by taking the sum of the biomass of all individual fish caught per trip. Catch per unit effort for each gear type was determined as:

$$
\begin{gathered}
C P U E=\text { total biomass } * \text { number of } \text { fisher }^{-1} \\
* \text { fishing } \text { time }^{-1}
\end{gathered}
$$

in which fishing time was in hours. To calculate fishing time, we subtracted the travel time from the total time of the fishing trip because we were interested in using CPUE to estimate catch, rather than using it to compare CPUE between sites or how CPUE changed over time, for which it would be important to include travel time. Trips in which multiple types of gear were used, or in which invertebrates were harvested, were not included for the purposes of calculating gear-specific CPUE. CPUE estimates were calculated for each trip and then averaged for each gear type across all sites. For gillnet fishing, a catch per set, rather than a catch per time period was calculated. CPUE estimates were within the range of other estimates in Fiji (Appendix 3).

Using the CPUE estimates, annual household catch for each gear type was estimated as:

\section{Estimated annual household catch $=C P U E_{\text {gear }} *$ mean fishing time gear$$
\text { * annual household fishing trips } \text { gear }
$$

Information on the frequency of household fishing trips was recalled for each gear type in the household interviews. Estimated household catches for handline fishing, day spearfishing, and night spearfishing were calculated separately for each gear type by multiplying the household's estimated number of annual fishing trips by the catch per unit effort and the mean trip time (the latter two metrics were calculated using the catch logs described above). For estimating household catch from gillnet trips, number of annual household gillnetting trips was multiplied by mean catch per set. Total estimated annual household catch was calculated by summing the estimated annual household catch of each gear type used.

We recognize that our indirect estimates of household catch are inflated compared with other catch landing data, disaggregated by gear, for Fiji (e.g., Bell et al. 2009). Recall bias has been shown to cause overestimation of fishing frequency, especially when multipliers are used, e.g., extrapolating weekly frequency to calculate an annual frequency (Vaske et al. 2003), as fishers are not likely to fish every week given poor weather, sickness, or events, e.g., weddings, that require travel out of the village. However, it is reasonable to assume that this recall bias is consistent across respondents, gear, and sites and, because our model seeks to assess the variation within household catch, and not predict the actual household catch; therefore, the likely inflation of estimates should not affect the model.

\section{Statistical analyses}

All potential drivers of fisheries catch were regressed against estimated annual household catch using general linear mixed models, with village as a random effect. We used structural equation modeling (Grace 2006) using the lavaan program (Rosseel 2012) in R (R Development Core Team 2015) to model drivers of fishing. We chose structural equation modeling over multiple regression because we wanted to take a systems approach, differentiate between direct and indirect drivers of fishing pressure, and because we expected that some of our 
Table 3. Descriptive statistics of potential social-ecological indicators of household fishing catch. ${ }^{\dagger}$ Dependent variable.

\begin{tabular}{|c|c|c|c|c|c|}
\hline Indicator & Mean & $\mathrm{SD}$ & & Min. & Max. \\
\hline Travel time to town & 143.4 & 94 & minutes & 30 & 300 \\
\hline Distance to town & 56 & 29.4 & $\mathrm{~km}$ & 16.7 & 92.9 \\
\hline Annual town visits & 32.1 & 40.3 & visits year $^{-1}$ & 0 & 364 \\
\hline Livelihood diversity & 7.8 & 2.2 & & 2 & 14 \\
\hline Income diversity & 5.2 & 2.2 & & 1 & 11 \\
\hline Local ecological knowledge & 4.9 & 2 & & 0 & 8.7 \\
\hline Connectedness & 6 & 2.5 & & 1 & 14 \\
\hline Estimated annual household $\operatorname{catch}^{\dagger}$ & 4638.5 & 3846.1 & $\mathrm{~kg}$ & 0 & 15023 \\
\hline Importance of fishing to income & 1.24 & 1.38 & & 0 & 4 \\
\hline Seafood consumption & 3.2 & 2 & days week ${ }^{-1}$ & 0 & 7 \\
\hline Material wealth & 2.7 & 1.9 & & 0 & 7 \\
\hline Reef area & 25.7 & 20.3 & $\mathrm{~km}^{2}$ & 1.4 & 52.2 \\
\hline
\end{tabular}

potential drivers would be correlated (Cullen et al. 2007, Cinner et al. 2007; Appendix 4). We first specified a hypothesized model based on published literature and our existing knowledge of the system (Fig. 1). Because the households were not a simple random sample of villages in Fiji, we used a model in which households were nested within villages. We used modification indices to identify missing paths, which may help to improve the model (Grace 2006), yet did not find any that were grounded in theory or existing knowledge, so no modifications were made. Nonsignificant drivers (determined by examining p-values) were then sequentially eliminated and the best-fit model was determined from comparing all models using Akaike's Information Criterion (AIC; Grace 2006; Appendix 5).

\section{RESULTS}

Over $96 \%$ of households interviewed participated in some fishing activity and $33 \%$ of households reported fishing as one of their top three income sources (Table 3). Our household surveys revealed a large amount of variation in household-level measures (Fig. 3, Appendix 1). Travel time to town, livelihood diversity, LEK, connectedness, importance of fishing to income, and fresh seafood consumption were all positively correlated $(\mathrm{p}<0.05)$ with estimated mean annual household catch (Fig. 4).

Fresh seafood consumption averaged 3.2 days week $^{-1}$ and ranged from 0 to 7 . The number of livelihoods averaged 7.8 and ranged from 2 to 14 (Fig. 3). Fishing, farming of taro (Colocasia esculenta), kava (Piper methysticum), and coconut (Cocos nucifera), along with formal employment were the most common livelihood sources. However, different livelihood sources provided the top source of income in different villages. For example, in villages close to urban areas and large resorts, about half of households listed formal employment as their top income source. In contrast, over half of households in the remaining villages responded that farming is their top livelihood source. Less common sources of livelihood included handicrafts, small businesses, and remittances.

Despite the variation in LEK, certain kinds of LEK were common across households. Most respondents had some knowledge of local species names, some knew about target fish diets, but few knew of fish spawning times. Of those that knew of spawning times, most only knew of grouper spawning periods, possibly the result of a recent national campaign to avoid eating groupers during their spawning season.
In the best fit structural equation model ( $\chi 2=0.61$, Fig. 5), importance of fishing to income, livelihood diversity, fresh seafood consumption, total reef area, and travel time to market all had direct significant positive effects on estimated mean annual household fish catch (Appendix 5). Travel time to market was a direct driver of livelihood diversity and was thus also an indirect driver of estimated household fish catch. Overall the model explained approximately one third of the variation in estimated household fish catch $\left(\mathrm{R}^{2}=0.31\right)$. Fish catch sold had the strongest effect (standardized path coefficient $=0.27$ ) on estimated household fish catch.

\section{DISCUSSION}

By using fine-scale, context appropriate social-ecological indicators and assessing their potential role in driving householdlevel fishing, we found trends that have not emerged in larger scale analyses on this topic. For example, in contrast to other studies that have found fishing pressure to increase with increasing proximity to markets (Brewer et al. 2012), we found that households further from town have higher fishing frequencies.

\section{Distance to market and middlemen}

Market integration, defined by distance to town and/or markets, has been found to be a negative driver of reef fish biomass (Cinner and McClanahan 2006, Cinner et al. 2013, Maire et al. 2016, McClanahan et al. 2016) and positive driver of fishing pressure (Brewer et al. 2012). Instead of relying on a single measure, we collected several indicators of market integration (distance to market, distance to fish sale location, travel time to market, frequency of market visits, importance of fishing to income, and population of nearest town). Of these, the best predictor was importance of fishing to income, a measure not based on proximity to market. Adding the population of the nearest town did not improve the model. Travel time to market was a significant positive driver of estimated household fish catch, meaning that households in villages further from towns had the highest fishing frequencies. The widespread presence of middlemen in Fiji may be one explanation for this finding. Middlemen buy goods, e.g., seafood and crops, directly from producers, e.g., fishers and farmers, and in turn sell to retailers or consumers. The role of middlemen in rural coral reef fisheries have also been reported elsewhere (Crona et al. 2010, Brewer 2011). In Fiji, middlemen are based in or regularly visit rural areas, essentially bringing markets to rural villages (Mangubhai et al. 2016). The presence of middlemen in rural areas may help to explain why we found 
Fig. 3. Variation in social indicators within and among villages. Districts are indicated on the x-axis. Boxplots show median value (solid band), fist quartile (bottom of box), third quartile (top of box), values that fall within 1.5 times of the interquartile range (dotted lines), and outliers (points).
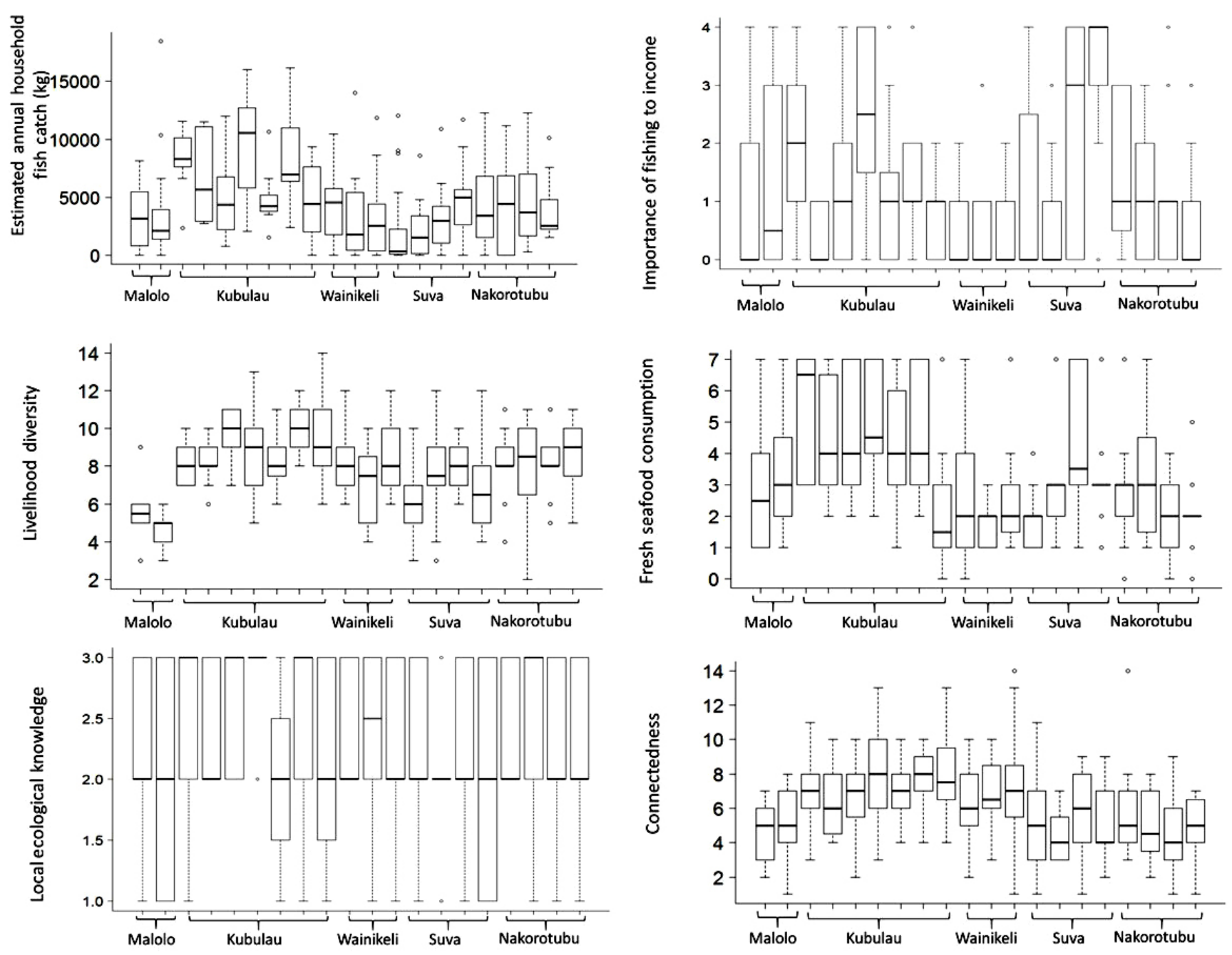

that households further from markets had higher estimated annual catches (Fig. 1). In Kubulau District, the district furthest from towns in this study, $75 \%$ of fishers sell fish directly to middlemen.

We were unable to accurately include a measure of distance to middleman in the model because households are not linked to a single middleman or place of fish sale. Some households may only sell fish to middlemen at times when cash is unexpectedly needed, e.g., funerals, or when larger sums of money are needed, e.g., church contributions or school-related expenses. Other households regularly sell at both the market and to middlemen. They decide between the two based on their yield or species of fish caught. Our data suggests that household decisions about whether and where to sell fish is dynamic. Assuming that sites further from markets are less at risk of overharvesting can lead to ineffective policies and insufficient funding for management of remote sites, particularly where middlemen may act as moving markets. Further information on the presence and role of middlemen in Pacific Island communities could facilitate effective management adapted to the realities and diversity of local circumstances. Value chain analysis, which maps the flow of goods and their values as they pass between actors, do consider the role of middlemen, and are increasingly useful in the management of small-scale fisheries (Thyresson et al. 2013, Wamukota et al. 2014).

\section{Drivers of estimated household fish catch}

Resource managers must have a comprehensive understanding of how social and ecological systems are connected at a local level to avoid bolstering social resilience at the expense of ecological resilience, or vice versa. Our research suggests that introducing additional income generating sources may be successful in increasing livelihood diversity of households, but may not reduce fishing levels, and therefore will not likely increase ecological resilience. Like many rural residents in developing countries, 
Fig. 4. Single variable regressions (with district as random variable) of potential drivers of household fishing. All relationships are statistically significant $(\mathrm{p}<0.05)$ where regression lines are present.

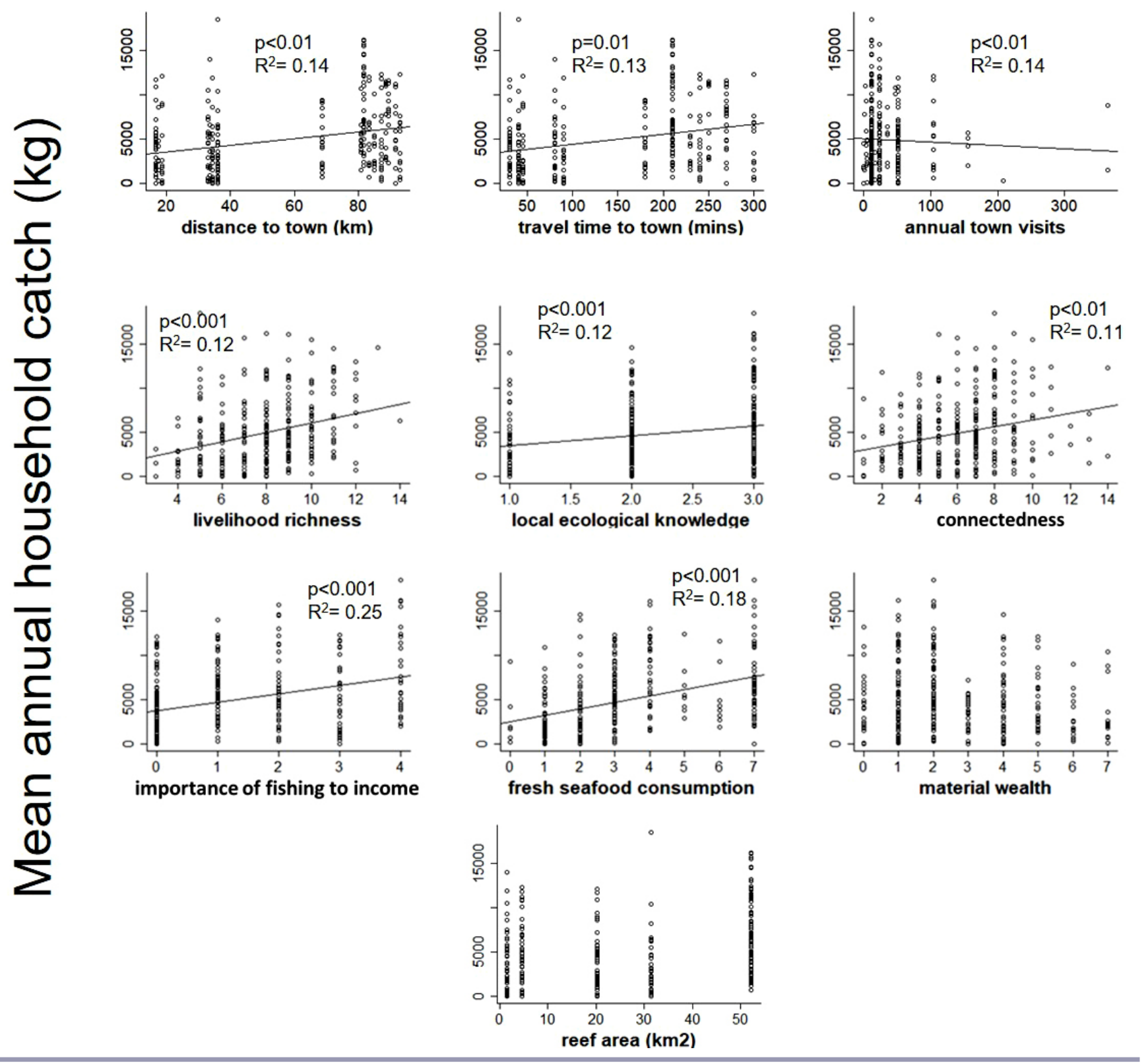

fishers commonly have diversified livelihoods to compensate for the seasonality and high variability inherent in small-scale fisheries (Allison and Ellis 2001, Cinner et al. 2010). Past studies suggest that households with high livelihood diversity may have increased resilience to disturbances, e.g., natural disasters or economic shocks, because they are able to spread risk across each of their livelihood sources (Allison and Ellis 2001). However, we found livelihood diversity was a significant positive driver of estimated annual household catch, indicating that households with more livelihood sources may also be catching more fish. This finding contradicts the assumptions of projects that introduce alternative livelihoods as a means to relieve fishing pressure, which are often popular with conservation agencies (Wright et al. 2016). Reviews of alternative livelihood projects, however, have shown that introducing additional income sources does not necessarily reduce resource extraction (Jupiter et al. 2014, Roe et al. 2015) because sometimes households do not find the introduced livelihood as a suitable substitute (Wright et al. 2016). In the Pacific, where fish and fishing are central to culture and identity, alternative livelihoods may not provide resources needed for traditional events, allow individuals to carry out their traditional roles, or provide opportunities for knowledge transmission. Instead, alternative livelihood sources may just serve as supplemental income (see also Sievanen et al. 2005). 
Fig. 5. Best fit structural equation model of social-ecological drivers of household fishing catch. All paths are positive and significant $(\mathrm{p}<0.05)$. Values are standardized path coefficients. Additional model statistics can be found in Appendix 5.

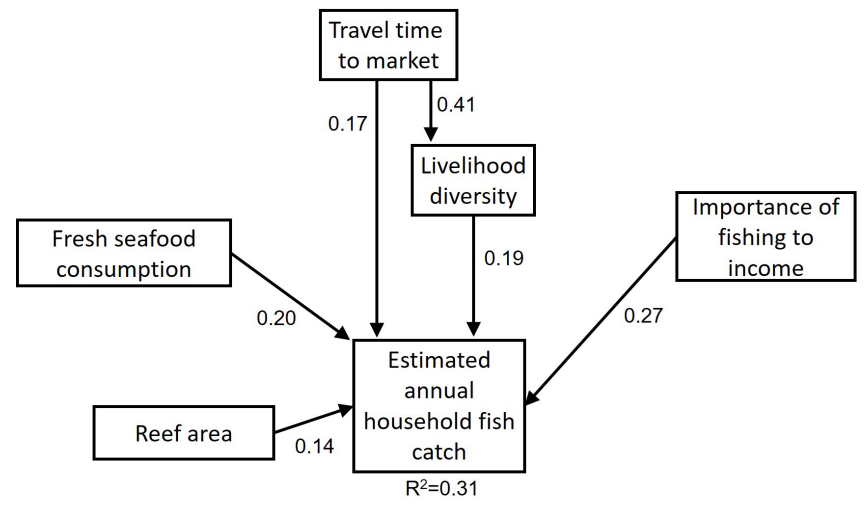

It is important to note that our measure of livelihood diversity is simply the number of livelihood sources, and does not take into account how much income each livelihood provides nor the quantity of nonmonetary goods a livelihood source may generate. However, we found the importance of fishing for income to be a stronger driver of household fishing than household consumption of fish. This suggests that efforts to reduce fishing for consumption may have less impact at reducing total catch than efforts to reduce fishing for income.

Although LEK was not a significant predictor in the structural equation model, it is significantly, positively correlated with estimated household fish catch (Fig. 4). This means that households with more LEK catch more fish. In our interviews, $37 \%$ of respondents said that they are not passing down the knowledge of local fish names, a form of LEK. Many of these respondents noted that they are not doing so because there is not an opportunity to do so (e.g., they do not go fishing with their children, children prefer watching television) or because they think their children learn the things they need to know at school. LEK has influenced natural resource use for centuries (Johannes 1978, 1981, Berkes 1999) and has potential to guide formal and informal contemporary place-based management (Berkes et al. 2000, Thornton and Maciejewski Scheer 2012). However, market influences may motivate fishers to use their LEK to increase harvests, e.g., target spawning aggregations of grouper or harvest gravid mud crabs, rather than to protect resources.

Although LEK and connectedness were not the strongest predictors of household fishing in our study, both influence fishing (Fig. 4) and should be further examined in future studies. Other, less structured types of surveys could be used to assess a broader suite of LEK that may influence fishing activities. For example, future surveys could examine the role of LEK in fishing practices by asking questions about how fishers determine fishing locations or the time at which they target certain species, along with asking about their fishing practices at these locations or times. In addition, although trust, exchange, norms, and connectedness make up social capital, we only measured exchange as a component of social capital. A more detailed examination of social networks that assesses metrics besides degree (number of connections per house) or incorporates other types of exchange, e.g., information, could better document the role of social capital in driving household fishing.

Future studies should also consider reef productivity along with reef area. The standing biomass can be influenced by natural environmental factors or anthropogenic factors and will impact CPUE, thus influencing fish catch. Finally, although we have investigated the drivers of estimated household catch, we acknowledge that it is not only the absolute biomass of fish extracted that will impact the ecology of reefs, but also the composition of the catch, which may be related to gear types used. A basic exploratory analysis of household social factors associated with different gear types can be found in Appendix 6 . Trophic level, size, and reproductive status of individual fish in catches are important to consider when assessing sustainability of fishing practices (Jennings and Kaiser 1998, Friedlander and DeMartini 2002, Graham et al. 2005, Mumby et al. 2006). Further studies should examine if and how social indicators are related to additional catch characteristics.

\section{Importance of considering household-level characteristics}

In contrast to studies that have used socioeconomic surrogates of fishing pressure (Mora 2008, Williams et al. 2008, Brewer et al. 2012), we used reported fishing activity to estimate household fishing levels. However, we also measured commonly used fishing pressure proxies (population density, mean number of boats per household, and mean number of refrigerators per household). Consistent with Weeks et al. (2010), we found that although the more easily measured metrics may be effective at generalizing total fishing pressure at a high spatial scale, they do a poor job of characterizing more heterogeneous fishing patterns found in communities. For example, we found that the villages that had the highest levels of household fishing were those with few boats and almost no refrigerators (Fig. 6). If managers are aiming to develop regulations that focus on local-level fishing, a broad understanding of mean fishing levels in an area may not be helpful, given the large variation in household fishing catch (Fig. 3, Appendix 1) and commonly used proxies may even misguide managers on the levels of fishing occurring in an area.

An example of this occurred in Fiji after Cyclone Winston, which hit February 2016. In a postcyclone survey conducted to estimate impacts of fisheries dependent communities, village leaders were asked to rank their villages' top livelihood source before the cyclone (Chaston Radway et al. 2016). We asked the same question, in some of the same villages, at a household-level and found that village-level results inflate the importance of fisheries in villages. If these village-level results are used to guide resource allocation for fishing gear replacement, villages might end up with more fishing gear than they had before the cyclone, and as a result, fishing levels could increase at a time when reefs are particularly vulnerable.

We understand that resources are not always available for household surveys, especially in times of crisis, such as after a major disaster. However, when possible, household-level surveys should be a priority. Our household surveys revealed a large amount of variation in household-level measures (Fig. 3), which is not surprising given the heterogeneities that exist within a 
Fig. 6. Mean household fish catch and commonly used proxies of fishing pressure: (a) population density in persons $/ \mathrm{km}$ of coastline, (b) mean number of boats per household, and (c) number of refrigerators per household. Relationships are statistically significant $(p<0.05)$ where regression line is present. In Fig. $6 \mathrm{~b}$ and $6 \mathrm{c}$ the $y$-axis does not cross the the $\mathrm{x}$-axis at 0 to better display the low values of mean number of boats and fridges per household.
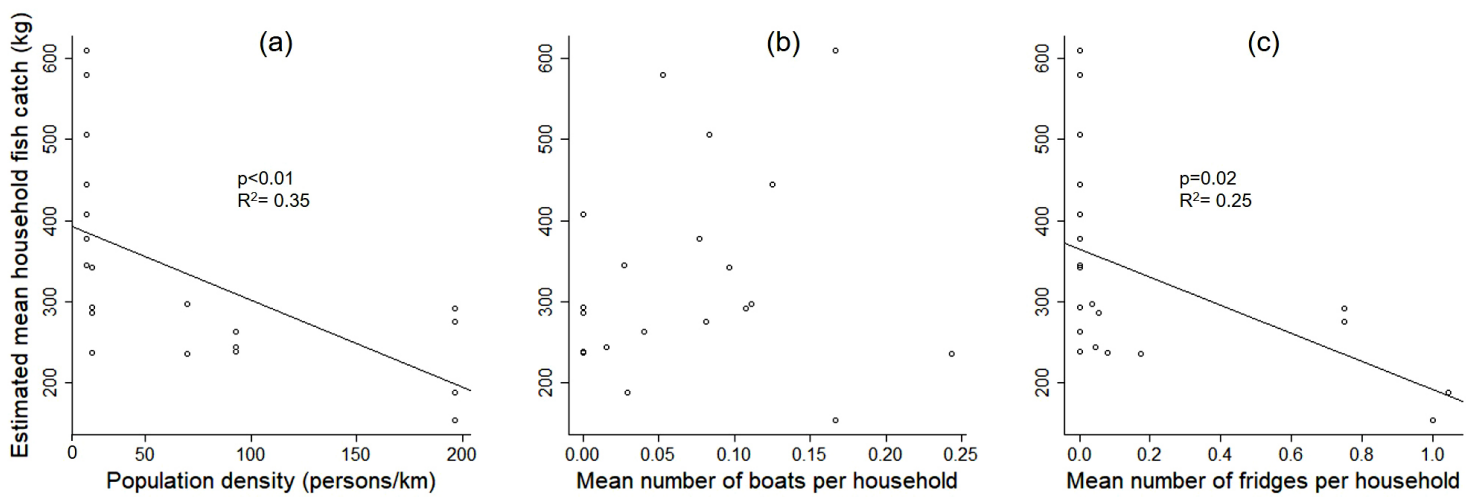

community. Instead of trying to aggregate at a community level, a more accurate, yet challenging way to understand the diverse interests and behaviors of different actors is to focus on understanding "patterns of difference" within a community (Agrawal and Gibson 1999). Factors that may affect how decisions are made about fishing and the fate of fisheries resources that could not be represented in this type of quantitative analysis, and require a more nuanced study, include household responsibilities based on religion, traditional roles, and relationships with other households and communities (Veitayaki et al. 2014).

\section{CONCLUSION}

For effectively managing small-scale coral reef fisheries, it is necessary to move beyond a community-level understanding of drivers of fishing and consider the drivers of individual or household behaviors (Aswani et al. 2015). Simple measures of social factors that are being applied worldwide have greatly improved our understanding of how human dimensions are related to resource use, but not all of these measurements are appropriate at smaller spatial scales, which is the scale at which most management decisions are made. Finer-scale data better captures the variation of fishing within a community and the nuances that affect how decisions are made about fishing and the use of fisheries resources, and as such will allow for a better idea of the implications of different management measures.

Responses to this article can be read online at: http://www.ecologyandsociety.org/issues/responses. php/9989

\section{Acknowledgments:}

This work would not have been possible without all the village members that generously volunteered their time for our surveys and graciously hosted us during our field work. We thank those who helped with household surveys and field work logistics: Rosi Batibasaga, Una Vuli, Mesulame Tora, Shimona Quazi, Seini Tawakelevu, Laisiasa Cavakiqali. Thanks to Rick Stepp for advising on the social network analysis. We also thank the Wildlife Conservation Society Fiji for their logistical support, the University of Hawaii NSF Coastal SEES working group for their feedback, and editors and reviewers for their thorough comments. Funding was provided by NSF GRFP Award \#1329626, NSF Coastal SEES Award \#SES-1325874, NSF CNIC Award \#OISE-1160830, and the University of Hawaii Graduate Student Organization. Use of human studies in this research was approved through IRB exemption \#CHS-20991.

\section{LITERATURE CITED}

Agrawal, A., and C. C. Gibson. 1999. Enchantment and disenchantment: the role of community in natural resource conservation. World Development 27(4):629-649. http://dx.doi. org/10.1016/S0305-750X(98)00161-2

Allison, E. H., and F. Ellis. 2001. The livelihoods approach and management of small-scale fisheries. Marine Policy 25 (5):377-388. http://dx.doi.org/10.1016/S0308-597X(01)00023-9

Andréfouët, S., F. E. Muller-Karger, J. A. Robinson, C. J. Kranenburg, D. Torres-Pulliza, S. A. Spraggins, and B. Murch. 2006. Global assessment of modern coral reef extent and diversity for regional science and management applications: a view from space. Proceedings of 10th International Coral Reefs Symposium 1745:1732-1745.

Asian Development Bank Economic Research and Regional Cooperation Department. 2015. Fiji: building inclusive institutions for sustained growth: country diagnostic study. Asian Development Bank, Manila, Philippines.

Aswani, S., P. J. Mumby, A. C. Baker, P. Christie, L. J. McCook, R. S. Steneck, and R. H. Richmond. 2015. Scientific frontiers in the management of coral reefs. Frontiers in Marine Science 2 (July):1-13. http://dx.doi.org/10.3389/fmars.2015.00050 
Bell, J. D., M. Kronen, A. Vunisea, W. J. Nash, G. Keeble, A. Demmke, S. Pontifex, and S. Andréfouët. 2009. Planning the use of fish for food security in the Pacific. Marine Policy 33(1):64-76. http://dx.doi.org/10.1016/j.marpol.2008.04.002

Berkes, F. 1999. Sacred ecology: traditional ecological knowledge and resource management. Taylor \& Francis, Philadelphia, Pennsylvania, USA.

Berkes, F., J. Colding, and C. Folke. 2000. Rediscovery of traditional ecological knowledge as adaptive management. Ecological Applications 10:1251-1262. http://dx.doi.org/10.1890/1051-0761 (2000)010[1251:ROTEKA]2.0.CO;2

Brandes, U., and D. Wagner. 2004. Analysis and visualization of social networks. Graph drawing software. Springer, Berlin, Germany. http://dx.doi.org/10.1007/978-3-642-18638-7 15

Brewer, T. 2011. Coral reef fish value chains in Solomon Islands: market opportunities and market effects on fish stocks. Report to Solomon Islands Ministry of Fisheries and Marine Resources and Secretariat of the Pacific Community. ARC Centre of Excellence for Coral Reef Studies, James Cook University, Townsville, Australia.

Brewer, T. D., J. E. Cinner, R. Fisher, A. Green, and S. K. Wilson. 2012. Market access, population density, and socioeconomic development explain diversity and functional group biomass of coral reef fish assemblages. Global Environmental Change 22 (2):399-406. http://dx.doi.org/10.1016/j.gloenvcha.2012.01.006

Brewer, T. D., J. E. Cinner, A. Green, and J. M. Pandolfi. 2009. Thresholds and multiple scale interaction of environment, resource use, and market proximity on reef fishery resources in the Solomon Islands. Biological Conservation 142(8):1797-1807. http://dx.doi.org/10.1016/j.biocon.2009.03.021

Brugère, C., K. Holvoet, and E. H. Allison. 2008. Livelihood diversification in coastal and inland fishing communities: misconceptions, evidence and implications for fisheries management. Working Paper, Sustainable Fisheries Livelihoods Programme (SFLP) FAO/DFID. Food and Agriculture Organization, Rome, Italy.

Bruno, J. F., and E. R. Selig. 2007. Regional decline of coral cover in the Indo-Pacific: timing, extent, and subregional comparisons. PLoS ONE 2(8):e711. http://dx.doi.org/10.1371/journal.pone.0000711

Burke, L., K. Reytar, M. Spalding, and A. Perry. 2011. Reefs at risk: revisited. World Resources Institute, Washington, D.C., USA.

Campbell, J. R. 2015. Development, global change and traditional food security in Pacific Island countries. Regional Environmental Change 15(7):1313-1324. http://dx.doi.org/10.1007/ s10113-014-0697-6

Charlton, K. E., J. Russell, E. Gorman, Q. Hanich, A. Delisle, B. Campbell, and J. Bell. 2016. Fish, food security and health in Pacific Island countries and territories: a systematic literature review. BMC Public Health 16(1):285. http://dx.doi.org/10.1186/ $\underline{\text { s12889-016-2953-9 }}$

Chaston Radway, K., M. Manley, S. Mangubhai, E. Sokowaqanilotu, W. Lalavanua, A. Bogiva, A. Caginitoba, T. Delai, M. Draniatu, S. Dulunaqio, M. Fox, I. Koroiwaqa, W.
Naisilisili, A. Rabukawaqa, K. Ravonoloa, and T. Weibi. 2016. Impact of tropical cyclone Winston on fisheries: dependent communities in Fiji. Wildlife Conservation Society, Suva, Fiji.

Cheal, A. J., M. A. MacNeil, E. Cripps, M. J. Emslie, M. Jonker, B. Schaffelke, and H. Sweatman. 2010. Coral-macroalgal phase shifts or reef resilience: links with diversity and functional roles of herbivorous fishes on the Great Barrier Reef. Coral Reefs 29 (4):1005-1015. http://dx.doi.org/10.1007/s00338-010-0661-y

Cinner, J. E. 2014. Coral reef livelihoods. Current Opinion in Environmental Sustainability 7:65-71. http://dx.doi.org/10.1016/j. cosust.2013.11.025

Cinner, J. E., and S. Aswani. 2007. Integrating customary management into marine conservation. Biological Conservation 140(3-4):201-216. http://dx.doi.org/10.1016/j.biocon.2007.08.008

Cinner, J. E., and Ö. Bodin. 2010. Livelihood diversification in tropical coastal communities: a network-based approach to analyzing "livelihood landscapes." PLoS ONE 5(8):e11999. http://dx.doi.org/10.1371/journal.pone.0011999

Cinner, J. E., N. A. J. Graham, C. Huchery, and M. A. Macneil. 2013. Global effects of local human population density and distance to markets on the condition of Coral Reef Fisheries. Conservation Biology 27(3):453-458. http://dx.doi.org/10.1111/ j.1523-1739.2012.01933.X

Cinner, J. E., and T. R. McClanahan. 2006. Socioeconomic factors that lead to overfishing in small-scale coral reef fisheries of Papua New Guinea. Environmental Conservation 33(1):73-80. http://dx. doi.org/10.1017/S0376892906002748

Cinner, J. E., T. R. McClanahan, T. M. Daw, N. A. J. Graham, J. Maina, S. K. Wilson, and T. P. Hughes. 2009. Linking social and ecological systems to sustain coral reef fisheries. Current Biology 19(3):206-212. http://dx.doi.org/10.1016/j.cub.2008.11.055

Cinner, J. E., T. R. McClanahan, and A. W. Wamukota. 2010. Differences in livelihoods, socioeconomic characteristics, and knowledge about the sea between fishers and non-fishers living near and far from marine parks on the Kenyan coast. Marine Policy 34(1):22-28. http://dx.doi.org/10.1016/j.marpol.2009.04.003

Cinner, J. E., S. Sutton, and T. Bond. 2007. Socioeconomic thresholds that affect use of customary fisheries management tools. Conservation Biology 21(6):1603-1611. http://dx.doi. org/10.1111/j.1523-1739.2007.00796.x

Clarke, P., and S. D. Jupiter. 2010. Law, custom and communitybased natural resource management in Kubulau District (Fiji). Environmental Conservation 37(1):98-106. http://dx.doi.org/10.1017/ $\underline{\mathrm{S} 0376892910000354}$

Crona, B. I., M. Nyström, C. Folke, and N. Jiddawi. 2010. Middlemen, a critical social-ecological link in coastal communities of Kenya and Zanzibar. Marine Policy 34 (4):761-771. http://dx.doi.org/10.1016/j.marpol.2010.01.023

Cullen, L. C., J. N. Pretty, D. J. Smith, and S. Pilgrim. 2007. Links between local ecological knowledge and wealth in indigenous communities of Indonesia: implications for conservation of marine resources. International Journal of Interdisciplinary Social Sciences 2(1). 
D'Arcy, P. 2006. The people of the sea: environment, identity, and history in Oceania. University of Hawai'i Press, Honolulu, Hawai'i, USA.

Dalzell, P. J., T. J. H. Adams, and N. V. C. Polunin. 1996. Coastal fisheries in the Pacific islands. Oceanography and Marine Biology 34:395-531.

Dulvy, N. K., R. P. Freckleton, and N. V. C. Polunin. 2004. Coral reef cascades and the indirect effects of predator removal by exploitation. Ecology Letters 7(5):410-416. http://dx.doi. org/10.1111/j.1461-0248.2004.00593.X

Fiji Bureau of Statistics (FBoS). 2007. Census of population and housing. Fiji Bureau of Statistics, Suva, Fiji. [online] URL: http:// www.statsfiji.gov.fj/statistics/2007-census-of-population-and-housing

Foale, S. 1998. Assessment and management of the trochus fishery at West Nggela, Solomon Islands: an interdisciplinary approach. Ocean and Coastal Management 40(2-3):187-205. http://dx.doi.org/10.1016/S0964-5691(98)00044-1

Foale, S., P. Cohen, S. Januchowski-Hartley, A. Wenger, and M. Macintyre. 2011. Tenure and taboos: origins and implications for fisheries in the Pacific. Fish and Fisheries 12(4):357-369. http://dx. doi.org/10.1111/j.1467-2979.2010.00395.x

Friedlander, A. M., and E. E. DeMartini. 2002. Contrasts in density, size, and biomass of reef fishes between the northwestern and the main Hawaiian islands: the effects of fishing down apex predators. Marine Ecology Progress Series 230:253-264. http://dx. doi.org/10.3354/meps 230253

Friedlander, A. M., J. M. Shackeroff, and J. N. Kittinger. 2013. Customary marine resource knowledge and use in contemporary Hawai'i. Pacific Science 67(3):441-460. http://dx.doi.org/10.2984/67.3.10

Gardner, T. A., I. M. Côté, J. A. Gill, A. Grant, and A. R. Watkinson. 2003. Long-term region-wide declines in Caribbean corals. Science 301(5635):958-960. http://dx.doi.org/10.1126/ science. 1086050

Grace, J. B. 2006. Structural equation modeling and natural systems. Cambridge University Press, Cambridge, UK. http://dx. doi.org/10.1017/CBO9780511617799

Graham, N. A. J., N. K. Dulvy, S. Jennings, and N. V. C. Polunin. 2005. Size-spectra as indicators of the effects of fishing on coral reef fish assemblages. Coral Reefs 24(1):118-124. http://dx.doi. org/10.1007/s00338-004-0466-y

Heithaus, M. R., A. Frid, A. J. Wirsing, and B. Worm. 2008. Predicting ecological consequences of marine top predator declines. Trends in Ecology and Evolution 23(4):202-210. http:// dx.doi.org/10.1016/j.tree.2008.01.003

Hughes, T. P., M. J. Rodrigues, D. R. Bellwood, D. Ceccarelli, O. Hoegh-Guldberg, L. McCook, N. Moltschaniwskyj, M. S. Pratchett, R. S. Steneck, and B. Willis. 2007. Phase shifts, herbivory, and the resilience of coral reefs to climate change. Current Biology 17(4):360-365. http://dx.doi.org/10.1016/j. cub.2006.12.049

Jennings, S., and M. J. Kaiser. 1998. The effects of fishing on marine ecosystems. Advances in Marine Biology 34:201-212, 212e, 213-352. http://dx.doi.org/10.1016/S0065-2881(08)60212-6
Johannes, R. E. 1978. Traditional marine conservation methods in Oceania and their demise. Annual Review of Ecology and Systematics 9(1):349-364. http://dx.doi.org/10.1146/annurev. es.09.110178.002025

Johannes, R. E. 1981. Words of the lagoon: fishing and marine lore in the Palau district of Micronesia. University of California Press, Berkeley, California, USA.

Jupiter, S. D., P. Clarke, S. R. Prasad, D. P. Egli, T. Tui, A. Caginitoba, and I. Qauqau. 2010. Non-compliance compliance with management rules and its implications for traditional inshore fisheries in Fiji. Wildlife Conservation Society, Suva, Fiji.

Jupiter, S. D., P. J. Cohen, R. Weeks, A. Tawake, and H. Govan. 2014. Locally-managed marine areas: multiple objectives and diverse strategies. Pacific Conservation Biology 20(2):165-179. http://dx.doi.org/10.1071/PC140165

Kittinger, J. N., L. T. Teneva, H. Koike, K. A. Stamoulis, D. S. Kittinger, K. L. L. Oleson, E. Conklin, M. Gomes, B. Wilcox, and A. M. Friedlander. 2015. From reef to table: social and ecological factors affecting coral reef fisheries, artisanal seafood supply chains, and seafood security. PLoS ONE 10(8):e0123856. http://dx.doi.org/10.1371/journal.pone.0123856

Kramer, D. B., G. Urquhart, and K. Schmitt. 2009. Globalization and the connection of remote communities: a review of household effects and their biodiversity implications. Ecological Economics 68(12):2897-2909. http://dx.doi.org/10.1016/j.ecolecon.2009.06.026

Kulbicki, M., N. Guillemot, and M. Amand. 2005. A general approach to length-weight relationships for New Caledonian lagoon fishes. Cybium 29(3):235-252.

Kuster, C., V. C. Vuki, and L. P. Zann. 2006. Validation of the accuracy of household reporting of subsistence fishing catch and effort: a Fijian case study. Fisheries Management and Ecology 13 (3):177-184. http://dx.doi.org/10.1111/j.1365-2400.2006.00492.x

Maire, E., J. Cinner, L. Velez, C. Huchery, C. Mora, S. Dagata, L. Vigliola, L. Wantiez, M. Kulbicki, and D. Mouillot. 2016. How accessible are coral reefs to people? A global assessment based on travel time. Ecology Letters 19:351-360. http://dx.doi. org/10.1111/ele. 12577

Mangubhai, S., Y. Nand, R. Ram, M. Fox, and M. TabunakawaiVakalalabure, and T. Vodivodi. 2016. Value chain analysis of the wild caught sea cucumber fishery in Fiji. Wildlife Conservation Society, Suva, Fiji. http://dx.doi.org/10.19121/2016.Report. DMX3207000000

Matthews, E., J. Veitayaki, and V. R. Bidesi. 1998. Fijian villagers adapt to changes in local fisheries. Ocean and Coastal Management 38(3):207-224. http://dx.doi.org/10.1016/S0964-5691 (97)00040-9

McClanahan, T. R., J. E. Cinner, J. Maina, N. A. J. Graham, T. M. Daw, S. M. Stead, A. Wamukota, K. Brown, M. Ateweberhan, V. Venus, and N. V. C. Polunin. 2008. Conservation action in a changing climate. Conservation Letters 1(2):53-59. http://dx.doi. org/10.1111/j.1755-263X.2008.00008 1.X

McClanahan, T. R., J. M. Maina, N. A. J. Graham, and K. R. Jones. 2016. Modeling fish biomass, recovery potential, and management priorities in the Western Indian Ocean. PLoS ONE 11(5):e0154585. http://dx.doi.org/10.1371/journal.pone.0154585 
McClanahan, T. R., M. J. Marnane, J. E. Cinner, and W. E. Kiene. 2006. A comparison of marine protected areas and alternative approaches to coral-reef management. Current Biology 16 (14):1408-1413. http://dx.doi.org/10.1016/j.cub.2006.05.062

McMillen, H. L., T. Ticktin, A. Friedlander, S. D. Jupiter, R. Thaman, J. Campbell, J. Veitayaki, T. Giambelluca, S. Nihmei, E. Rupeni, L. Apis-Overhoff, W. Aalbersberg, and D. F. Orcherton. 2014. Small islands, valuable insights: systems of customary resource use and resilience to climate change in the Pacific. Ecology and Society 19(4):44. http://dx.doi.org/10.5751/ ES-06937-190444

Minter, A. 2008. Compliance and enforcement for coastal fisheries management in Fiji. International Union for the Conservation of Nature and Natural Resources Regional Office for Oceania, Suva, Fiji.

Moberg, F., and C. Folke. 1999. Ecological goods and services of coral reef ecosystems. Ecological Economics 29(2):215-233. http:// dx.doi.org/10.1016/S0921-8009(99)00009-9

Mora, C. 2008. A clear human footprint in the coral reefs of the Caribbean. Proceedings of the Royal Society B: Biological Sciences 275(1636):767-773. http://dx.doi.org/10.1098/rspb.2007.1472

Mora, C., O. Aburto-Oropeza, A. Ayala-Bocos, P. M. Ayotte, S. Banks, A. G. Bauman, M. Beger, S. Bessudo, D. J. Booth, E. Brokovich, A. Brooks, P. Chabanet, J. E. Cinner, J. Cortés, J. J. Cruz-Motta, A. Cupul-Magaña, E. E. DeMartini, G. J. Edgar, D. A. Feary, S. C. A. Ferse, A. M. Friedlander, K. J. Gaston, C. Gough, N. A. J. Graham, A. Green, H. Guzman, M. Hardt, M. Kulbicki, Y. Letourneur, A. Ĺpez-Pérez, M. Loreau, Y. Loya, C. Martinez, I. Mascareñas-Osorio, T. Morove, M. O. Nadon, Y. Nakamura, G. Paredes, N. V. C. Polunin, M. S. Pratchett, H. Reyes Bonilla, F. Rivera, E. Sala, S. A. Sandin, G. Soler, R. Stuart-Smith, E. Tessier, D. P. Tittensor, M. Tupper, P. Usseglio, L. Vigliola, L. Wantiez, I. Williams, S. K. Wilson, and F. A. Zapata. 2011. Global human footprint on the linkage between biodiversity and ecosystem functioning in reef fishes. PLoS Biology 9(4):e1000606. http://dx.doi.org/10.1371/journal.pbio.1000606

Mumby, P. J., C. P. Dahlgren, A. R. Harborne, C. V. Kappel, F. Micheli, D. R. Brumbaugh, K. E. Holmes, J. M. Mendes, K. Broad, J. N. Sanchirico, K. Buch, S. Box, R. W. Stoffle, and A. B. Gill. 2006. Fishing, trophic cascades, and the process of grazing on coral reefs. Science 311(5757):98-101. http://dx.doi. org/10.1126/science.1121129

Nabobo-Baba, U. 2011. Decolonising framings in Pacific research: indigenous Fijian Vanua research framework as an organic response. AlterNative: An International Journal of Indigenous Peoples 4(2):140-154. http://dx.doi.org/10.1177/1177$\underline{18010800400210}$

Newton, K., I. M. Côté, G. M. Pilling, S. Jennings, and N. K. Dulvy. 2007. Current and future sustainability of island coral reef fisheries. Current Biology 17(7):655-658. http://dx.doi.org/10.1016/ j.cub.2007.02.054

Oles, B. 2007. Transformations in the sociocultural values and meanings of reefs and resources on Mwoakilloa. Coral Reefs 26 (4):971-981. http://dx.doi.org/10.1007/s00338-007-0225-y

Pascua, P., H. McMillen, T. Ticktin, M. Vaughan, and K. B. Winter. 2017. Beyond services: a process and framework to incorporate cultural, genealogical, place-based, and indigenous relationships in ecosystem service assessments. Ecosystem Services 26(Part B):465-475. http://dx.doi.org/10.1016/j. ecoser.2017.03.012

Poepoe, K. K., P. K. Bartram, and A. M. Friedlander. 2007. The use of traditional knowledge in the contemporary management of a Hawaiian community's marine resources. Fishers' Knowledge in Fisheries Science and Management 119-143.

Pretty, J. 2003. Social capital and the collective management of resources. Science 302(5652):1912-1914. http://dx.doi.org/10.1126/ science. 1090847

R Development Core Team. 2015. R Internals. R Foundation for Statistical Computing, Vienna, Austria.

Ravuvu, A. 1983. Vaka i Taukei: The Fijian Way of Life. Institute of Pacific Studies of the University of the South Pacific, Suva, Fiji.

Ravuvu, A. 1988. Development or dependence. Institute of Pacific Studies of the University of the South Pacific, Suva, Fiji.

Rawlinson, N. J. F., D. A. Milton, S. J. M. Blaber, A. Sesewa, and S. P. Sharma. 1995. A survey of the subsistence and artisanal fisheries in rural areas of Viti Levu, Fiji. Australian Centre for International Agricultural Research Monograph, Canberra, Australia.

Roe, D., F. Booker, M. Day, W. Zhou, S. Allebone-Webb, N. A. O. Hill, N. Kumpel, G. Petrokofsky, K. Redford, D. Russell, G. Shepherd, J. Wright, and T. C. H. Sunderland. 2015. Are alternative livelihood projects effective at reducing local threats to specified elements of biodiversity and/or improving or maintaining the conservation status of those elements? Environmental Evidence 4:22. http://dx.doi.org/10.1186/s13750-015-0048-1

Rosseel, Y. 2012. lavaan: an R Package for structural equation modeling. Journal of Statistical Software 48(2):1-36. http://dx. doi.org/10.18637/jss.v048.i02

Sandin, S. A., J. E. Smith, E. E. Demartini, E. A. Dinsdale, S. D. Donner, A. M. Friedlander, T. Konotchick, M. Malay, J. E. Maragos, D. Obura, O. Pantos, G. Paulay, M. Richie, F. Rohwer, R. E. Schroeder, S. Walsh, J. B. C. Jackson, N. Knowlton, and E. Sala. 2008. Baselines and degradation of coral reefs in the Northern Line Islands. PLoS ONE 3(2):e1548. http://dx.doi. org/10.1371/journal.pone.0001548

Schemmel, E. M., and A. M. Friedlander. 2017. Participatory fishery monitoring is successful for understanding the reproductive biology needed for local fisheries management. Environmental Biology of Fishes 100(2):171-185. http://dx.doi. org/10.1007/s10641-016-0566-X

Severance, C., R. Franco, M. Hamnett, C. Anderson, and F. Aitaoto. 2013. Effort triggers, fish flow, and customary exchange in American Samoa and the northern Marianas: critical human dimensions of western pacific fisheries. Pacific Science 67 (3):383-393. http://dx.doi.org/10.2984/67.3.6

Sievanen, L., B. Crawford, R. B. Pollnac, and C. Lowe. 2005. Weeding through assumptions of livelihood approaches in ICM: seaweed farming in the Philippines and Indonesia. Ocean \& Coastal Management 48(3-6):297-313. http://dx.doi.org/10.1016/ j.ocecoaman.2005.04.015 
Sloan, J., and K. Chand. 2015. A review of near shore fisheries law \& governance in Fiji. Siwatibau \& Sloan, Suva, Fiji.

Sloan, J., and K. Chand. 2016. An analysis of property rights in the Fijian qoliqoli. Marine Policy 72:76-81. http://dx.doi. org/10.1016/j.marpol.2016.06.019

Sterling, E. J., C. Filardi, A. Toomey, A. Sigouin, E. Betley, N. Gazit, J. Newell, S. Albert, D. Alvira, N. Bergamini, M. Blair, D. Boseto, K. Burrows, N. Bynum, S. Caillon, J. E. Caselle, J. Claudet, G. Cullman, R. Dacks, P. Eyzaguirre, S. Gray, J. Herrera, P. Kenilorea, K. Kinney, N. Kurashima, S. Macey, C. Malone, S. Mauli, J. McCarter, H. McMillen, P. Pascua, P. Pikacha, A. Porzecanski, R. de Pascale, M. Salpeteur, M. Sirikolo, M. Stege, T. Stege, T. Ticktin, R. Vave, A. Wali, P. West, K. B. Winter, and S. D. Jupiter. 2017. Biocultural approaches to well-being and sustainability indicators across scales. Nature Ecology and Evolution 1:1798-1806. http://dx.doi.org/10.1038/s41559-017-0349-6

Teh, L. C. L., L. S. L. Teh, B. Starkhouse, and U. Rashid Sumaila. 2009. An overview of socio-economic and ecological perspectives of Fiji's inshore reef fisheries. Marine Policy 33(5):807-817. http:// dx.doi.org/10.1016/j.marpol.2009.03.001

Teh, L. S. L., L. C. L. Teh, and U. R. Sumaila. 2013. A global estimate of the number of coral reef fishers. PLOS ONE 8(6): e65397. http://dx.doi.org/10.1371/journal.pone.0065397

Thaman, R., T. Fong, and A. Balawa. 2008. Biodiversity and ethnobiodiversity of finfishes of Navakavu, Viti Levu, Fiji Islands. SPRH - FIO Biodiversity and Ethnobiodiversity Report. No. 4. The University of the South Pacific Suva, Fiji.

Thornton, T. F., and A. Maciejewski Scheer. 2012. Collaborative engagement of local and traditional knowledge and science in marine environments: a review. Ecology and Society 17(3):8. http://dx.doi.org/10.5751/ES-04714-170308

Thyresson, M., B. I. Crona, M. Nyström, M. de la Torre-Castro, and N. Jiddawi. 2013. Tracing value chains to understand effects of trade on coral reef fish in Zanzibar, Tanzania. Marine Policy 38:246-256. http://dx.doi.org/10.1016/j.marpol.2012.05.041

Turner, R. A., A. Cakacaka, N. A. J. Graham, N. V. C. Polunin, M. S. Pratchett, S. M. Stead, and S. K. Wilson. 2007. Declining reliance on marine resources in remote South Pacific societies: ecological versus socio-economic drivers. Coral Reefs 26 (4):997-1008. http://dx.doi.org/10.1007/s00338-007-0238-6

Vaske, J., T. C. Huan, and J. Beaman. 2003. The use of multiples in anglers' recall of participation and harvest estimates: some results and implications. Leisure Sciences 25:399-409. http://dx. doi.org/10.1080/714044498

Vaughan, M. B., and P. M. Vitousek. 2013. Mahele: sustaining communities through small-scale inshore fishery catch and sharing networks. Pacific Science 67(3):329-344. http://dx.doi. org/10.2984/67.3.3

Veitayaki, J. 2002. Taking advantage of indigenous knowledge: the Fiji case. International Social Science Journal 54(173):395-402. http://dx.doi.org/10.1111/1468-2451.00391

Veitayaki, J., A. Breckwoldt, T. Sigarua, and N. Bulai. 2014. Living from the sea: culture and marine conservation in Fiji. iTaukei Trust Fund, Suva, Fuji.
Wamukota, A., T. D. Brewer, and B. Crona. 2014. Market integration and its relation to income distribution and inequality among fishers and traders: the case of two small-scale Kenyan reef fisheries. Marine Policy 48:93-101. http://dx.doi.org/10.1016/ j.marpol.2014.03.013

Weeks, R., G. R. Russ, A. A. Bucol, and A. C. Alcala. 2010. Shortcuts for marine conservation planning: the effectiveness of socioeconomic data surrogates. Biological Conservation 143 (5):1236-1244. http://dx.doi.org/10.1016/j.biocon.2010.02.031

Wildlife Conservation Society (WCS). 2012. Ecosystem-based management plan: Kubulau District, Vanua Levu, Fiji. Wildlife Conservation Society, Suva, Fiji.

Williams, I. D., W. J. Walsh, R. E. Schroeder, A. M. Friedlander, B. L. Richards, and K. A. Stamoulis. 2008. Assessing the importance of fishing impacts on Hawaiian coral reef fish assemblages along regional-scale human population gradients. Environmental Conservation 35(3):261-272. http://dx.doi.org/10.1017/ $\underline{\mathrm{S} 0376892908004876}$

Wright, J. H., N. A. O. Hill, D. Roe, J. M. Rowcliffe, N. F. Kümpel, M. Day, F. Booker, and E. J. Milner-Gulland. 2016. Reframing the concept of alternative livelihoods. Conservation Biology 30 (1):7-13. http://dx.doi.org/10.1111/cobi.12607

Zent, S. and L. Maffi. 2009. Final report on indicator no. 2: methodology for developing a vitality index of traditional environmental knowledge (VITEK) for the project "Global Indicators of the Status and Trends of Linguistic Diversity and Traditional Knowledge.” Terralingua, Salt Spring Island, British Columbia, Canada. 


\section{Appendix 1}

Table A1.1. Descriptive statistics of potential social-ecological indicators of household fishing catch by village

\begin{tabular}{|c|c|c|c|c|c|c|c|c|c|c|c|c|c|c|}
\hline District & Village & 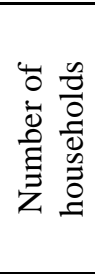 & 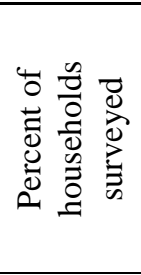 & 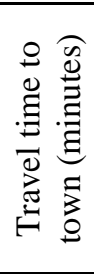 & 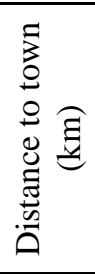 & 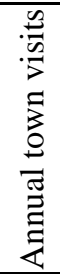 & 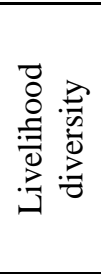 & 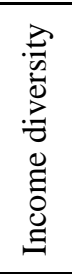 & 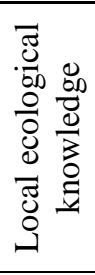 & 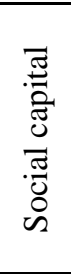 & 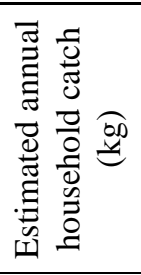 & 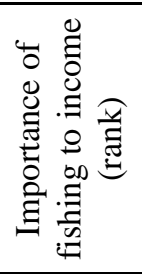 & 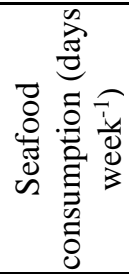 & 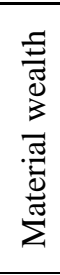 \\
\hline \multirow[t]{2}{*}{ Malolo } & Cubi & 27 & $78 \%$ & 40 & 36 & 22 & 4.7 & 3.1 & 1.9 & 5.0 & 3,484 & 1.4 & 3.4 & 2.8 \\
\hline & Solevu & 115 & $17 \%$ & 40 & 36 & 32 & 5.5 & 3.9 & 2.1 & 4.4 & 3,545 & 0.9 & 3.1 & 4.9 \\
\hline \multirow[t]{7}{*}{ Kubulau } & Kilaka & 37 & $54 \%$ & 180 & 69 & 15 & 9.4 & 6.3 & 2.1 & 7.8 & 4,879 & 0.7 & 2.1 & 2.2 \\
\hline & Kiobo & 13 & $92 \%$ & 210 & 83 & 25 & 9.7 & 6.6 & 2.5 & 6.7 & 5,347 & 1.3 & 4.8 & 2.5 \\
\hline & Namalata & 19 & $68 \%$ & 210 & 82 & 14 & 9.8 & 7.5 & 2.6 & 7.8 & 8,499 & 1.4 & 4.4 & 2.2 \\
\hline & Natokalau & 16 & $75 \%$ & 250 & 89 & 14 & 8.2 & 5.7 & 2.4 & 6.4 & 6,714 & 0.5 & 4.5 & 1.9 \\
\hline & Navatu & 30 & $67 \%$ & 210 & 82 & 15 & 8.8 & 6.4 & 2.8 & 7.9 & 9,624 & 2.4 & 5.0 & 1.8 \\
\hline & Raviravi & 18 & $83 \%$ & 210 & 81 & 27 & 8.3 & 5.5 & 2.0 & 6.9 & 4,728 & 1.1 & 4.4 & 2.2 \\
\hline & Waisa & 12 & $83 \%$ & 270 & 89 & 12 & 8.2 & 6.2 & 2.5 & 7.0 & 8,353 & 2.1 & 5.4 & 1.6 \\
\hline \multirow[t]{3}{*}{ Wainikeli } & Korovou & 65 & $31 \%$ & 90 & 35 & 20 & 8.3 & 5.6 & 2.1 & 7.5 & 3,011 & 0.6 & 2.8 & 1.7 \\
\hline & Vidawa & 21 & $57 \%$ & 80 & 34 & 33 & 7.6 & 4.6 & 2.4 & 6.7 & 4,047 & 0.5 & 1.9 & 1.7 \\
\hline & Waitabu & 25 & $68 \%$ & 80 & 33 & 30 & 8.2 & 5.4 & 2.3 & 6.3 & 4,554 & 0.6 & 2.8 & 1.7 \\
\hline \multirow[t]{4}{*}{ Suva } & Kalokolevu & 69 & $29 \%$ & 45 & 19 & 77 & 6.3 & 3.1 & 2.2 & 5.0 & 3,029 & 1.1 & 2.0 & 4.6 \\
\hline & Muaivuso & 37 & $54 \%$ & 30 & 17 & 62 & 8.1 & 4.4 & 2.3 & 5.6 & 3,369 & 2.0 & 4.2 & 4.4 \\
\hline & Togalevu & 18 & $67 \%$ & 45 & 18 & 98 & 8.8 & 4.9 & 2.1 & 4.6 & 2,944 & 0.8 & 3.0 & 5.6 \\
\hline & Waiqanake & 56 & $36 \%$ & 30 & 17 & 66 & 7.0 & 4.2 & 1.9 & 5.3 & 5,193 & 3.1 & 3.3 & 2.8 \\
\hline \multirow[t]{4}{*}{ Nakorotubu } & Namarai & 31 & $58 \%$ & 270 & 91 & 19 & 8.5 & 5.8 & 2.5 & 5.4 & 5,288 & 1.0 & 3.8 & 3.1 \\
\hline & Naocobau & 18 & $72 \%$ & 300 & 93 & 33 & 8.5 & 6.5 & 2.4 & 5.8 & 4,748 & 1.5 & 3.2 & 2.7 \\
\hline & Saioko & 20 & $95 \%$ & 240 & 87 & 19 & 8.2 & 6.1 & 2.2 & 4.4 & 4,573 & 0.9 & 1.8 & 2.1 \\
\hline & Verevere & 25 & $64 \%$ & 230 & 85 & 19 & 8.7 & 6.5 & 2.3 & 4.9 & 3,873 & 0.5 & 2.1 & 2.0 \\
\hline
\end{tabular}


Appendix 2. Section 1: Lessons learned from LEK questions from pilot survey; Section 2: Pilot survey; Section 3: Questions about local ecological knowledge (LEK) in the household survey; Section 4: Explanation of how total LEK score was calculated; Section 5: Social network analysis section from the household survey.

\section{Section 1}

Our pilot survey can be found, starting on the following page. The local ecological knowledge questions that were tested can be found in section IV. The questions were designed to ask about aspects of knowledge and practice. Below, we describe what we learned from three of these marine related pilot questions and the changes that were made for the final survey.

1. Do you plan your fishing activities according to:

Weather?

Moon phase?

Flowering plants?

Other:

In this question, almost every fisher mentioned at least one method, and it was thus difficult to determine a method to assess this question. We created a new question to assess practice in which we asked respondents whether or not they teach fish names to younger generations and why they do or do not partake in this practice.

\section{How many types of parrot fish can you name?}

In this question, we presented respondents with photos of different species of parrotfish, including some photos of the same species but in different phases. We found that most people only had 2-3 names for parrotfish as a species complex. We revised this question to include species from several different families that had documented names in some dialects.

\section{Have you noticed changes in the timing of fish reproduction? [probe: migration, egg production,} spawning]

We learned that many respondents had a hard time understanding what we were even asking about. We learned that it is somewhat common knowledge that some fish aggregate, but most of our respondents were unaware of the biological processes occurring during aggregations. From this experience, we made many changes to the spawning questions, including adding a description of fish aggregations. After we explained aggregations, we asked if the respondent knew of this behavior. If they did not, we did not ask further questions. If they did, we asked about the three species complexes and then an open-ended question in which we asked if they knew the timing of any other species or had anything else about spawning that they wished to share. The majority of the respondents knew about spawning times for groupers (likely due to a recent national campaign) and were clear in that they did not know about times for other species. 


\section{Investigating the complexities of coral reef social-ecological systems Household Surveys}

\section{Interviewer: \\ Interviewee: \\ Name of house: \\ Village name: \\ Date:}

\section{LIVELIHOOD OPTIONS}

Check all sources of income from which your household derives salary. [Must ask all]. Next, give interviewee 20 beans and ask them to distribute them among income sources to reflect each source's contribution (score) to total income. All sources that are checked must also have a score.

\begin{tabular}{|c|c|c|}
\hline & Income source & Score \\
\hline$\square$ & Fishing (saltwater finfish, shellfish) & \\
\hline$\square$ & Fishing (freshwater finfish, shellfish) & \\
\hline & Farming & \\
\hline$\square$ & Copra & \\
\hline$\square$ & Sea cucumbers & \\
\hline$\square$ & $\begin{array}{l}\text { Handicrafts (weaving, baskets, mats, masi, } \\
\text { sasa, fans, etc.) }\end{array}$ & \\
\hline$\square$ & Wages/salary from employment & \\
\hline$\square$ & Remittances & \\
\hline$\square$ & Land lease & \\
\hline$\square$ & House rent & \\
\hline$\square$ & Own business & \\
\hline & Other (specify): & \\
\hline & Other (specify): & \\
\hline & Other (specify): & \\
\hline & $\begin{array}{l}\text { TOTAL SCORE } \\
\text { (should add to 20) }\end{array}$ & \\
\hline
\end{tabular}




\section{AGRICULTURE}

Check all crops that are grown by members of this household. For every checked crop, ask how many varieties of the crop are grown. Also indicate if the crop is used for subsistence, sale, or to give away (can check more than one). If the crop is sold, indicate the location of sale.

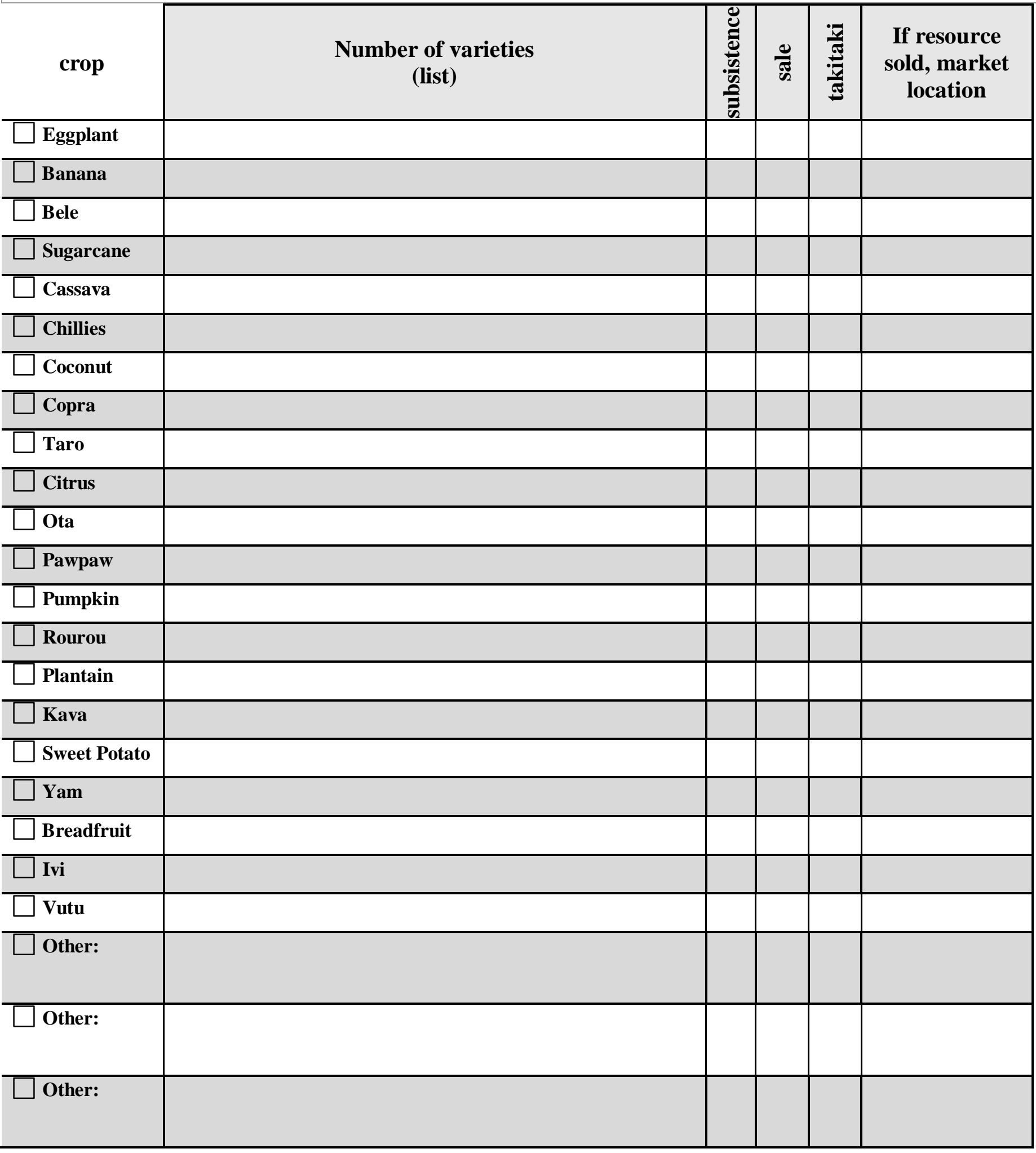

2a. Do you use chemical: (check if yes) $\square$ fertilizers? $\square$ pesticides? $\square$ herbicides? 


\section{FISHING}

Check all fishing activities performed by members of this household. For every checked method, ask the frequency of the activity and, as done previously, indicate what the harvest is used for.

\begin{tabular}{|c|c|c|c|c|c|}
\hline Fishing method & frequency & $\begin{array}{l}\frac{8}{0} \\
\frac{\pi}{0} \\
\frac{0}{5} \\
\frac{0}{5}\end{array}$ & $\frac{0}{\sigma_{n}}$ & 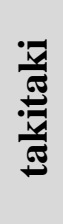 & $\begin{array}{c}\text { If resource sold, market } \\
\text { location }\end{array}$ \\
\hline$\square$ Hand line & $\begin{array}{l}\square \text { More than once a week } \\
\square \text { Once every 1-2 weeks } \\
\square \text { About once a month } \\
\square \text { Less than once a month }\end{array}$ & & & & \\
\hline $\begin{array}{l}\square \text { Spear fishing } \\
\text { (snorkeling) }\end{array}$ & $\begin{array}{l}\square \text { More than once a week } \\
\square \text { Once every 1-2 weeks } \\
\square \text { About once a month } \\
\square \text { Less than once a month }\end{array}$ & & & & \\
\hline$\square$ Gill net & $\begin{array}{l}\square \text { More than once a week } \\
\square \text { Once every } 1-2 \text { weeks } \\
\square \text { About once a month } \\
\square \text { Less than once a month }\end{array}$ & & & & \\
\hline$\square$ Cast net & $\begin{array}{l}\square \text { More than once a week } \\
\square \text { Once every 1-2 weeks } \\
\square \text { About once a month } \\
\square \text { Less than once a month }\end{array}$ & & & & \\
\hline$\square$ Fish basket & $\begin{array}{l}\square \text { More than once a week } \\
\square \text { Once every 1-2 weeks } \\
\square \text { About once a month } \\
\square \text { Less than once a month }\end{array}$ & & & & \\
\hline Other: & $\begin{array}{l}\square \text { More than once a week } \\
\square \text { Once every } 1-2 \text { weeks } \\
\square \text { About once a month } \\
\square \text { Less than once a month }\end{array}$ & & & & \\
\hline$\square$ Other: & $\begin{array}{l}\square \text { More than once a week } \\
\square \text { Once every } 1-2 \text { weeks } \\
\square \text { About once a month } \\
\square \text { Less than once a month }\end{array}$ & & & & \\
\hline$\square$ Other: & $\begin{array}{l}\square \text { More than once a week } \\
\square \text { Once every } 1-2 \text { weeks } \\
\square \text { About once a month } \\
\square \text { Less than once a month }\end{array}$ & & & & \\
\hline
\end{tabular}

3a. How often do you fish to contribute to an event (church, feast, relatives, etc):
Once a week
Once a month
Less than once a month
Other:

\section{3b. Do you plan your fishing activities according to:}

Weather?

Moon phase?

Flowering plants?

Other: 


\section{LOCAL KNOWLEDGE}

\begin{tabular}{|c|c|c|c|}
\hline $\begin{array}{l}\text { How many } \\
\text { varieties of taro } \\
\text { can you name? }\end{array}$ & $\begin{array}{l}1 . \\
2 . \\
3 . \\
4 .\end{array}$ & $\begin{array}{l}5 . \\
6 . \\
7 . \\
8 .\end{array}$ & $\begin{array}{l}9 . \\
10 . \\
11 . \\
12 .\end{array}$ \\
\hline $\begin{array}{l}\text { How many uses } \\
\text { of [important } \\
\text { plant] can you } \\
\text { think of? }\end{array}$ & $\begin{array}{l}1 . \\
2 . \\
3 . \\
4 .\end{array}$ & $\begin{array}{l}5 . \\
6 . \\
7 . \\
8 .\end{array}$ & $\begin{array}{l}9 . \\
10 . \\
11 . \\
12 .\end{array}$ \\
\hline $\begin{array}{l}\text { Can you name } \\
\text { the types of trees } \\
\text { that grow in or } \\
\text { around your } \\
\text { taro? }\end{array}$ & $\begin{array}{l}1 . \\
2 . \\
3 . \\
4 .\end{array}$ & $\begin{array}{l}5 . \\
6 . \\
7 . \\
8 .\end{array}$ & $\begin{array}{l}9 . \\
10 . \\
11 . \\
12 .\end{array}$ \\
\hline $\begin{array}{l}\text { How many types } \\
\text { of parrot fish } \\
\text { can you name? }\end{array}$ & $\begin{array}{l}1 . \\
2 . \\
3 . \\
4 .\end{array}$ & $\begin{array}{l}5 . \\
6 . \\
7 . \\
8 .\end{array}$ & $\begin{array}{l}9 . \\
10 . \\
11 . \\
12 .\end{array}$ \\
\hline
\end{tabular}

4b. What do you do to your plantation after harvest:

$\square$ Let it lay fallow. If so, how long?

$\square$ Plant a cover crop $\square$ Till remaining plant matter into soil

$\square$ Other:

4c. Have you planted any new crops or varieties in the last 10 years that are more resistant to salt, cyclones, or drought? $\quad \square$ Yes $\quad \square$ No

If yes, which ones?

4d. Have you noticed changes in the timing of plant maturation? [probe: budding, flowering, fruiting]

Yes. Explain:

$\square$ No.

4e. Have you noticed changes in the timing of fish reproduction? [probe: migration, egg production, spawning]

$\square$ Yes. Explain:

$\square$ No. 


\section{MARKET ACCESSIBILITY}

5a. How often do you buy things from the market?

More than once

a week

Once a week

More than once a month

Other:

5b. How often do you buy things from the village canteen?

Once a week $\quad \square$ Once a month $\square$ Less than once a month $\square$ Other:

5c. How do you travel to the nearest market? (check all that apply)
Bus
$\square$ Carrier
Boat
Other:

5d. How long does it take to reach the nearest market?
Less than 1 hour
1-2 hours
2-4 hours
More than 4 hours

5e. How much does it cost to travel to the nearest market? (one way)

Transportation method:

Cost:

Transportation method:

Cost:

Transportation method:

Cost: 
VI. MATERIAL ASSETS

Check all that apply for the household.

\begin{tabular}{|c|c|}
\hline House construction: & $\begin{array}{l}\square \text { Tin } \\
\square \text { Wood } \\
\square \text { Brick } \\
\square \text { Traditional materials } \\
\square \text { Other: }\end{array}$ \\
\hline Toilet facility: & $\begin{array}{l}\square \text { Pit } \\
\square \text { Water seal } \\
\square \text { Flush } \\
\square \text { Other: }\end{array}$ \\
\hline Appliances: & $\begin{array}{l}\square \text { Radio } \\
\square \text { Television } \\
\square \text { DVD player } \\
\square \text { Mobile phone } \\
\square \text { Laptop/tablet } \\
\square \text { Other: }\end{array}$ \\
\hline Lighting: & $\begin{array}{l}\square \text { Kerosene } \\
\square \text { Lamp (battery/rechargeable) } \\
\square \text { Electrical lights } \\
\square \text { Candles } \\
\square \text { Other: }\end{array}$ \\
\hline Cooking energy: & $\begin{array}{l}\square \text { firewood } \\
\square \text { kerosene } \\
\square \text { gas } \\
\square \text { Other: }\end{array}$ \\
\hline Own transportation: & $\begin{array}{l}\square \text { bilibili } \\
\square \text { non-motorized boat } \\
\square \text { boat with outboard engine } \\
\square \text { vehicle } \\
\square \text { Other: }\end{array}$ \\
\hline
\end{tabular}




\section{$\underline{\text { Section } 3}$}

Below are questions about local ecological knowledge (LEK) from the household survey. Note, this is an English translation of these questions. The actual survey was translated into the Fijian language and conducted in Fijian by native speakers.

\section{Traditional Ecological Knowledge}

For these questions, we do not aim to document your specific detailed knowledge, we are just trying to get a sense of what types of knowledge exist in this village. As with all of our questions, there are no right or wrong answers. If you do not know something, do not be ashamed to say "I don't know;" we are not here to judge you.

\section{Do you usually go fishing? YES NO}

2. We have several photos of fish found in Fiji. [Give respondent first set of cards] How many can you name? Please provide whatever name you know of-we are aware that names may be different throughout the country, so please give a local name if that's what you know. [Write down names with the number that corresponds with the number on the fish card]

Respondents were presented photos of the following species:

$\begin{array}{ll}\text { Family } & \text { Genus and species } \\ \text { Acanthuridae } & \text { Acanthurus xanthopterus } \\ \text { Belonidae } & \text { Tylosurus crocodilus } \\ \text { Carangidae } & \text { Carangoides ferdau } \\ \text { Chaetodontidae } & \text { Chaetodon lunula } \\ \text { Gerreidae } & \text { Gerres erythrourus } \\ \text { Gerreidae } & \text { Gerres oblongus } \\ \text { Haemulidae } & \text { Plectorhinchus chaetodonoides } \\ \text { Labridae } & \text { Cheilinus fasciatus } \\ \text { Labridae } & \text { Cheilinus undulatus (adult) } \\ \text { Labridae } & \text { Cheilinus undulatus (juvenile) } \\ \text { Lethrinidae } & \text { Lethrinus nebulosus } \\ \text { Lethrinidae } & \text { Lethrinus olivaceus } \\ \text { Lethrinidae } & \text { Monotaxis grandoculis } \\ \text { Lutjanidae } & \text { Lutjanus argentimaculatus } \\ \text { Lutjanidae } & \text { Lutjanus bohar } \\ \text { Scaridae } & \text { Bolbometopon muricatum } \\ \text { Scaridae } & \text { Chlorurus bleekeri } \\ \text { Serranidae } & \text { Cephalopholis argus } \\ \text { Serranidae } & \text { Epinephelus merra } \\ \text { Serranidae } & \text { Plectropomus leopardus }\end{array}$


3. Have you taught these names to anyone in a younger generation? YES NO

Why or why not?

You may know that fish come together, in groups, to reproduce.

4. Do you know the time of year when this occurs for any fish species?

[If yes] What about for: [note response and circle number that corresponds to level of knowledge] Groupers?

$0 \quad 1 \quad 2$

Parrotfish?

$0 \quad 1 \quad 2$

Emperorfish?

$0 \quad 1$

2

Any other species?

$0 \quad 1 \quad 2$

5. As you probably know, different fish eat different things. Do you know what the following fish eat?

Groupers?

$0 \quad 1 \longdiv { 2 }$

Parrotfish?

$0 \quad 1 \quad-2$

Emperorfish?

0

1 


\section{$\underline{\text { Section } 4}$}

\section{Scoring:}

Fish identification [Question 2]:

- 1 point for every answer that corresponded to the correct species name

- 0.5 points for every answer that corresponded to the correct general/family name

- 0 points given to answers that were known to apply to different species

Transmission [Question 3]:

- 1 point for YES

- 0 points for NO

Timing of fish spawning [Question 4]:

- Because timing of spawning may vary spatially and temporally:

- 1 point for any response

- 0 points for "do not know"

Fish diets [Question 5]:

- $\quad 0$ points if respondent did not know any diet items

- 1 point for every correct diet item mentioned

- $\quad 0.5$ points subtracted for every incorrect item mentioned (only subtracted from scores greater than zero).

\section{Total LEK score:}

$0.2 *$ Transmission $+0.4 *$ Fish identification $+0.4 *$ (Timing of fish spawning + Fish diets $)$ 


\section{$\underline{\text { Section } 5}$}

Below are the questions from the social network section of the household survey. Note, this is an English translation of these questions. The actual survey was translated into the Fijian language and conducted in Fijian by native speakers.

\section{Social Networks}

In the next set of questions, we ask who you share resources with. We know that sharing is very common in many cultures, including here in Fiji. In Hawaii, scientists have shown that the fish caught in one community may be widely dispersed to other parts of the island and beyond. Maintaining relationships can help in times of trouble. However, with recent social and environmental changes, many things are changing. We are interested in if/why/how sharing is changing. In this section, we will ask you to provide names of people. We just want to remind you that there are no right or wrong answers to these questions AND that we will not be sharing your personal information with anyone. We are not judging you.

[Surveyor then shows respondent an example of a network map (on last page) to explain how this data will be used]

27. In the past two weeks, to who have you provided resources in this village? (list more than one name OR name and house name for each listed- ex.: Jone, father of Mere)

- What is your relationship with whom you have provided?

[Eg. immediate family, non-immediate family, clan, church, chief, etc.)

-What resource was shared?

[e.g., fish, root crops, money, sugar]

\begin{tabular}{|l|l|l|l|}
\hline Name 1 & Name 2 & Relationship & Resource (s) \\
\hline & & & \\
\hline & & & \\
\hline & & & \\
\hline & & & \\
\hline & & & \\
\hline & & & \\
\hline & & & \\
\hline & & & \\
\hline
\end{tabular}


28. In the past two weeks, from who have you received resources from in this village? (list more than one name OR name and house name for each listed- ex.: Jone, father of Mere)

- What is your relationship with the providers?

[Eg. immediate family, non-immediate family, clan, church, chief, etc.)

-What resource was shared?

[e.g., fish, root crops, money, sugar]

\begin{tabular}{|l|l|l|l|}
\hline Name 1 & Name 2 & Relationship & Resource (s) \\
\hline & & & \\
\hline & & & \\
\hline & & & \\
\hline & & & \\
\hline & & & \\
\hline & & & \\
\hline & & & \\
\hline
\end{tabular}




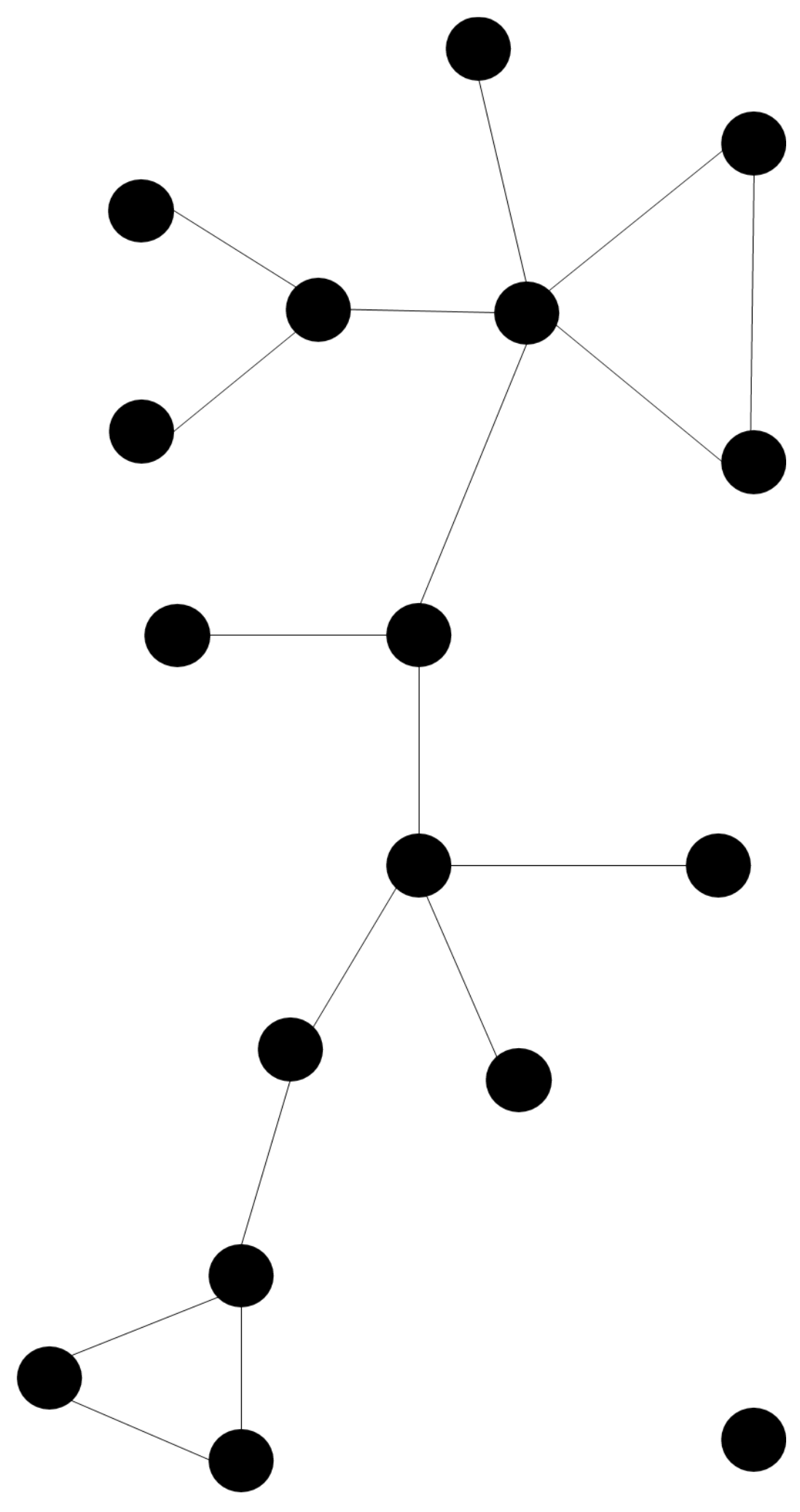




\section{Appendix 3}

Table A3.1. Comparison of catch per unit effort (CPUE) estimates in Fiji from this study and other studies. Table is adapted from Teh et al. 2009.

\begin{tabular}{lll}
\hline \hline Fishery & CPUE mean $( \pm$ s.e. $)$ & Reference \\
\hline Hand line & $2.27 \mathrm{~kg} \mathrm{line}^{-1} \mathrm{~h}^{-1}$ & Dalzell et al. 1996 \\
Hand line & $1.41 \pm 0.31 \mathrm{~kg} \mathrm{fisher}^{-1} \mathrm{~h}^{-1}$ & Rawlinson et al. 1995 \\
Hand line & $2.75 \pm 0.41 \mathrm{~kg} \mathrm{fisher}^{-1} \mathrm{~h}^{-1}$ & this study \\
Spear & $1.2 \mathrm{~kg} \mathrm{fisher}^{-1} \mathrm{~h}^{-1}$ & Dalzell et al. 1996 \\
Spear & $1.51 \mathrm{~kg} \mathrm{fisher}^{-1} \mathrm{~h}^{-1}$ & Dalzell et al. 1996 \\
Spear & $2.07 \pm 0.31 \mathrm{~kg} \mathrm{fisher}^{-1} \mathrm{~h}^{-1}$ & Kuster et al. 2006 \\
Spear (day) & $2.97 \pm 0.70 \mathrm{~kg} \mathrm{fisher}^{-1} \mathrm{~h}^{-1}$ & this study \\
Spear (night) & $3.80 \pm 1.10 \mathrm{~kg} \mathrm{fisher}^{-1} \mathrm{~h}^{-1}$ & this study \\
Gillnet & $18.9 \mathrm{~kg} \mathrm{set}^{-1}$ & Dalzell et al. 1996 \\
Gillnet & $31.8 \mathrm{~kg} \mathrm{set}^{-1}$ & Dalzell et al. 1996 \\
Gillnet & $24.76 \pm 8.68 \mathrm{~kg} \mathrm{set}^{-1}$ & this study \\
\hline
\end{tabular}




\section{Appendix 4}

Table A4.1. Correlation matrix of potential explanatory variables significance levels are indicated by: $p<.01$ ' $* *$ ', $\mathrm{p}<.05$ ' $*$ '

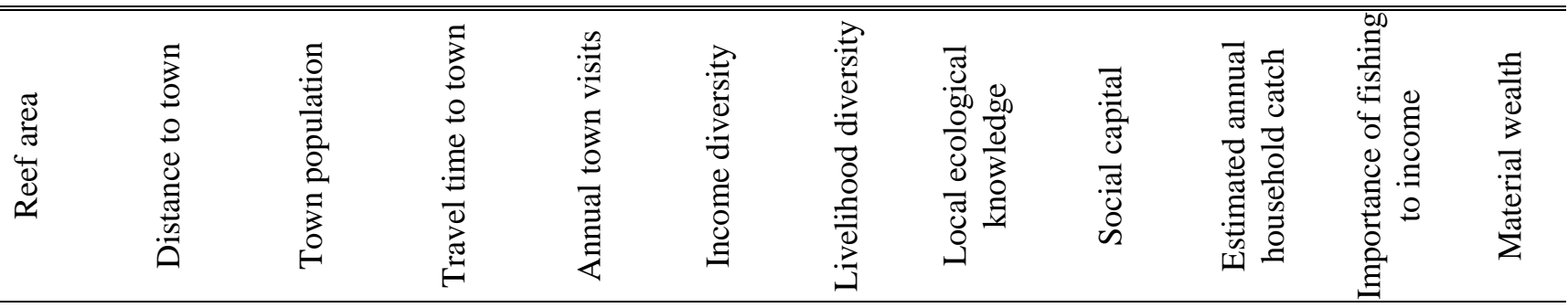

\begin{tabular}{|c|c|c|c|c|c|c|c|c|c|c|c|c|}
\hline \multicolumn{13}{|l|}{ Reef area } \\
\hline Distance to town & $0.32 * *$ & & & & & & & & & & & \\
\hline Town population & $-0.35 * *$ & $-0.49 * *$ & & & & & & & & & & \\
\hline Travel time to town & $0.22 * *$ & $0.98 * *$ & $-0.43 * *$ & & & & & & & & & \\
\hline Annual town visits & $-0.13^{*}$ & $-0.39 * *$ & $0.43 * *$ & $-0.34 * *$ & & & & & & & & \\
\hline Income diversity & 0.11 & $0.42 * *$ & $-0.30 * *$ & $0.44 * *$ & -0.09 & & & & & & & \\
\hline Livelihood diversity & 0.11 & $0.36 * *$ & $-0.26^{* *}$ & $0.41 * *$ & -0.09 & $0.81 * *$ & & & & & & \\
\hline Local ecological knowledge & 0.08 & $0.18 * *$ & $-0.12 *$ & $0.19 * *$ & 0.03 & $0.17 * *$ & $0.14^{*}$ & & & & & \\
\hline Connectedness & $0.24 * *$ & $0.14 *$ & $-0.36 * *$ & $0.15 *$ & $-0.15^{*}$ & $0.19 * *$ & $0.28 * *$ & $0.19 * *$ & & & & \\
\hline Estimated annual household catch & $0.30 * *$ & $0.29 * *$ & $-0.22 * *$ & $0.28 * *$ & -0.04 & $0.37 * *$ & $0.29 * *$ & $0.21 * *$ & $0.25 * *$ & & & \\
\hline Importance of fishing to income & $0.14^{*}$ & -0.08 & $0.19 * *$ & -0.07 & $0.14 *$ & $0.19 * *$ & 0.00 & $0.26 * *$ & 0.02 & $0.35 * *$ & & \\
\hline Material wealth & -0.05 & $-0.33 * *$ & $0.45^{* *}$ & $-0.33 * *$ & $0.32 * *$ & $-0.14 *$ & -0.07 & -0.06 & $-0.15^{* *}$ & $-0.16^{* *}$ & -0.08 & \\
\hline Seafood consumption & $0.33 * *$ & $0.15 * *$ & $-0.12 *$ & $0.13^{*}$ & -0.03 & $0.17 * *$ & $0.12 *$ & $0.32 * *$ & $0.18^{* *}$ & $0.39 * *$ & $0.38 * *$ & -0.06 \\
\hline
\end{tabular}




\section{Appendix 5}

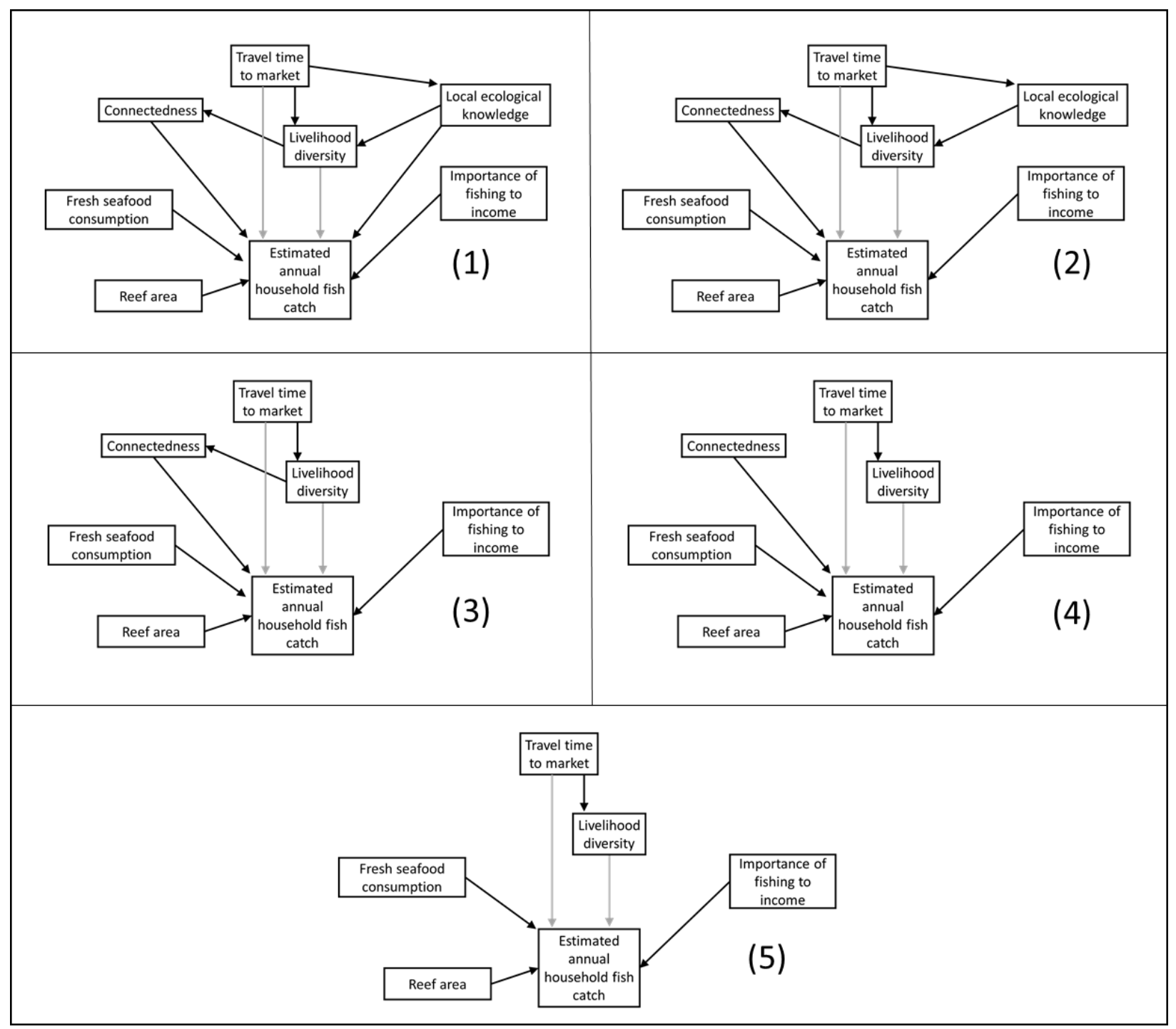

Figure A5.1. Comparison models. Model 1 is the hypothesized model and each subsequent model has had a non-significant variable removed. Model statistics are compared in Table A3.1 below. 
Table A5.1. List of AICc scores and other model statistics from candidate models.

\begin{tabular}{|c|l|c|c|}
\hline \hline Model & AICc & R2 & P-value (chi-square) \\
\hline 1 & 13535.7 & 0.29 & $<0.01$ \\
\hline 2 & 10458.8 & 0.31 & $<0.01$ \\
\hline 3 & 9828.44 & 0.31 & $<0.01$ \\
\hline 4 & 9821.92 & 0.32 & $<0.01$ \\
\hline 5 & 8454.59 & 0.31 & 0.61 \\
\hline
\end{tabular}

Table A5.2. Summary statistics of final model.

\begin{tabular}{lcccc}
\hline \hline & $\begin{array}{c}\text { Unstandardized } \\
\text { effect size }\end{array}$ & $\begin{array}{c}\text { Standardized } \\
\text { effect size }\end{array}$ & SE & p-value \\
\hline Effect on estimated household catch: & & & & \\
Seafood consumption & 0.37 & 0.199 & 0.113 & 0.001 \\
Importance of fishing to income & 0.738 & 0.272 & 0.177 & $<0.001$ \\
Livelihood diversity & 0.335 & 0.186 & 0.111 & 0.002 \\
Reef area & 0.261 & 0.142 & 0.127 & 0.04 \\
Travel time to town & 0.068 & 0.168 & 0.025 & 0.007 \\
& & & & \\
Effect on livelihood diversity: & & & & 0.001 \\
Travel time to town & 0.091 & 0.407 & 0.028 & \\
\hline
\end{tabular}




\section{Appendix 6}

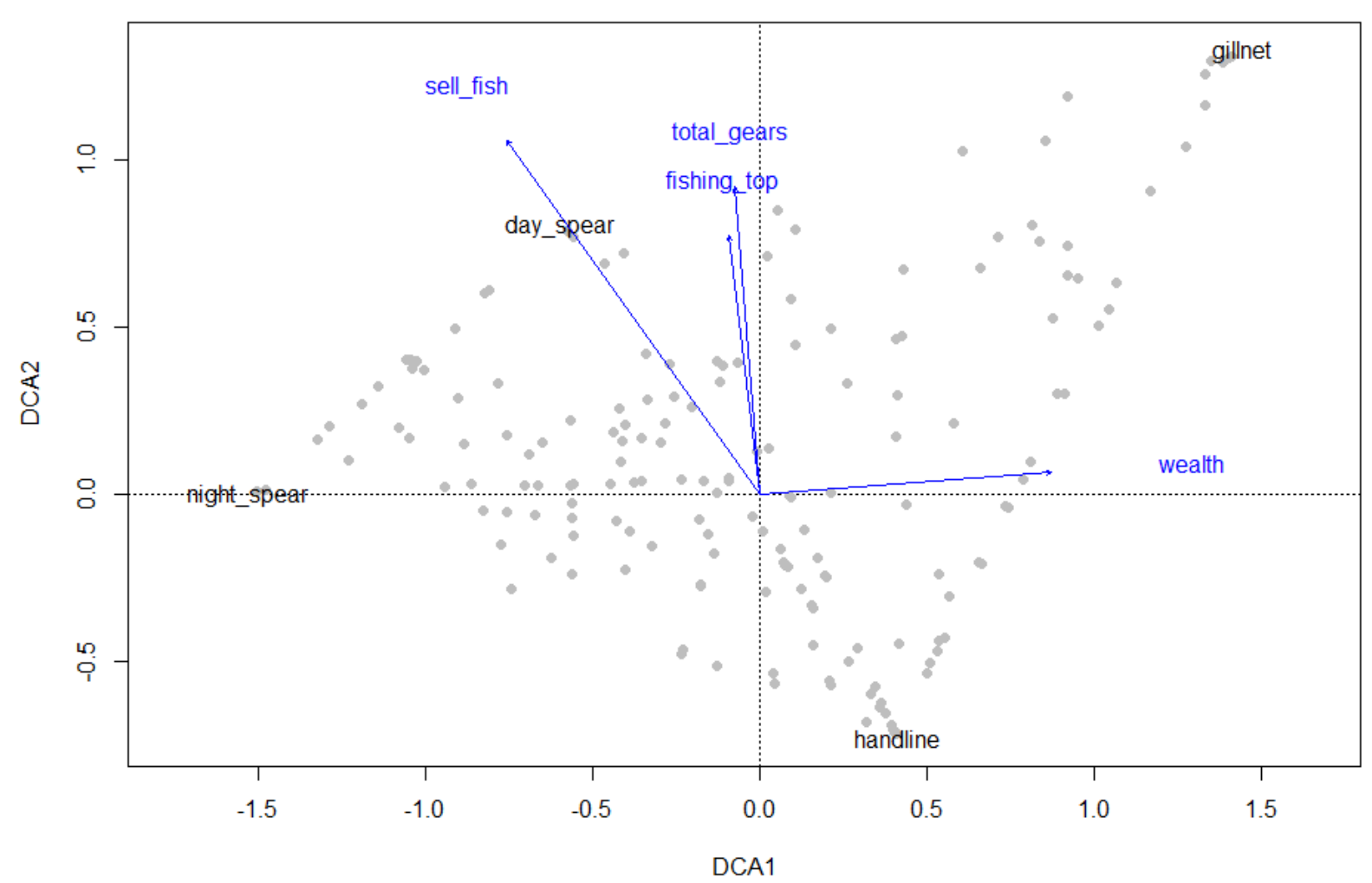

Figure A6.1. Results of detrended correspondence analysis (DCA) of household gear use assemblages. Household annual frequency of gear use (days) was plotted in multidimensional space. Axis 1: eigenvalue $=0.42$, Axis 2: 0.35 . Household socioeconomic data was fitted onto the ordination (only significant variables shown, where $\mathrm{p}<0.05$ ), where smaller angles between arrows gear types represent stronger correlations and the length of the arrow is proportional to the correlation with the ordination axes.

The plot of the results of the detrended correspondence analysis was homogeneous, with no clear clustering of households (Axis 1: eigenvalue= 0.42, Axis 2: 0.35) (Fig. 7). The overlayed socioeconomic data on the ordination showed that households with a top income source of fish or that sell any amount of fish are correlated with higher amounts of spear use. Households with higher numbers of gears are more correlated with spear and gillnet use than with handline use. Similarly, households with the highest measures of wealth were most correlated with households with higher gillnet usage. 